\title{
Radiometric Ages of Volcanic Rocks on the Fort Rock Dome and in the Aquarius Mountains, Yavapai and Mohave Counties, Arizona
}

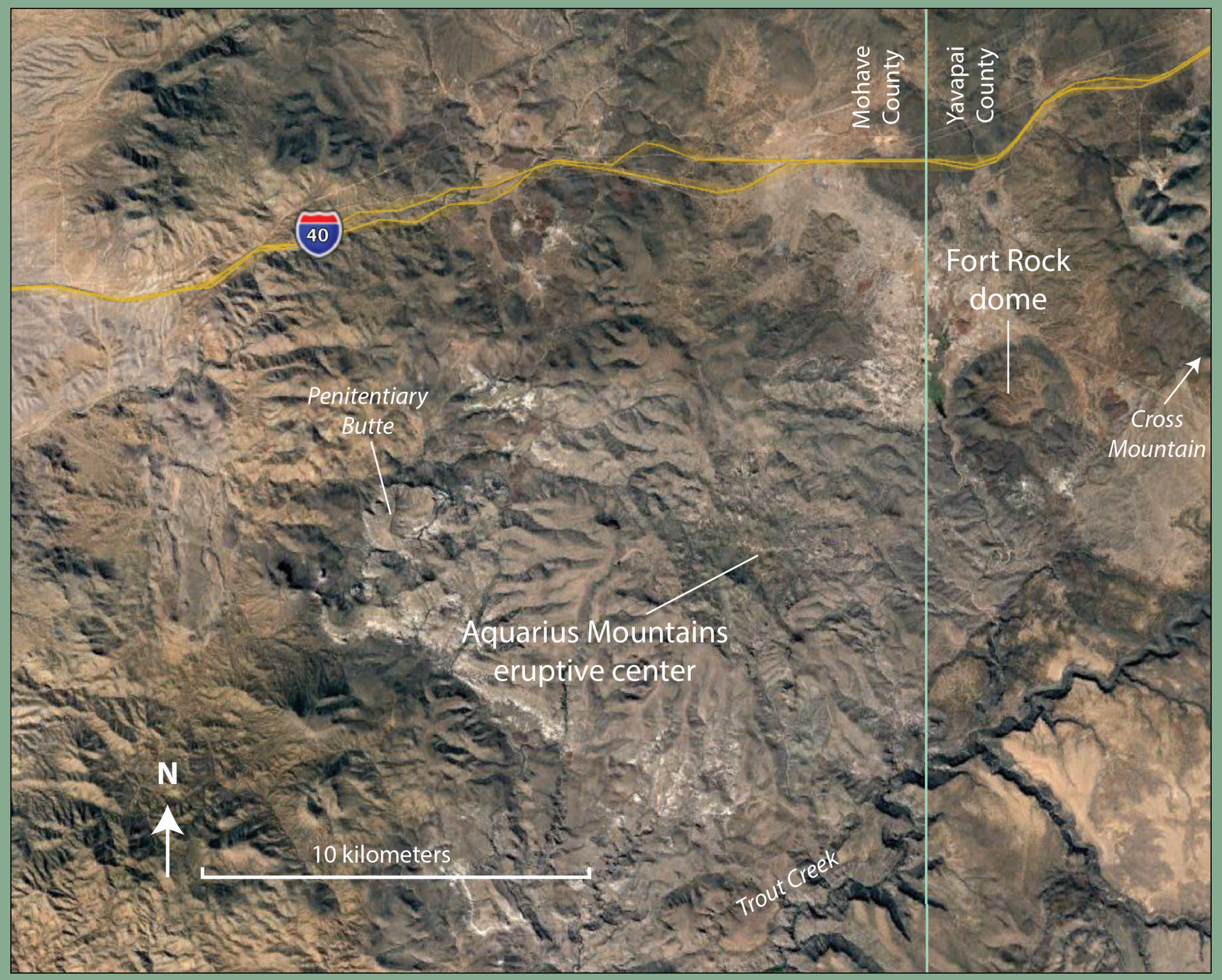

Open-File Report 2019-1038 
COVER. Satellite image of study area south of Interstate 40 near the border between Mohave county and Yavapai county, Arizona. 


\section{Radiometric Ages of Volcanic Rocks on the Fort Rock Dome and in the Aquarius Mountains, Yavapai and Mohave Counties, Arizona}

By Gary S. Fuis, Andrew Calvert, and Katie Sullivan

Open-File Report 2019-1038 


\title{
U.S. Department of the Interior DAVID BERNHARDT, Secretary
}

\author{
U.S. Geological Survey \\ James F. Reilly II, Director
}

U.S. Geological Survey, Reston, Virginia: 2019

For more information on the USGS - the Federal source for science about the Earth, its natural and living resources, natural hazards, and the environment-visit

https://www.usgs.gov or call 1-888-ASK-USGS (1-888-275-8747)

For an overview of USGS information products, including maps, imagery, and publications, visit https://store.usgs.gov.

Any use of trade, firm, or product names is for descriptive purposes only and does not imply endorsement by the U.S. Government.

Although this information product, for the most part, is in the public domain, it also may contain copyrighted materials as noted in the text. Permission to reproduce copyrighted items must be secured from the copyright owner.

Suggested citation:

Fuis, G.S., Calvert, A., and Sullivan, K., 2019, Radiometric ages of volcanic rocks on the Fort Rock dome and in the Aquarius Mountains, Yavapai and Mohave counties, Arizona: U.S. Geological Survey Open-File Report 2019-1038, 18 p., https://doi.org/10.3133/ofr20191038.

ISSN 2331-1258 (online) 


\section{Contents}

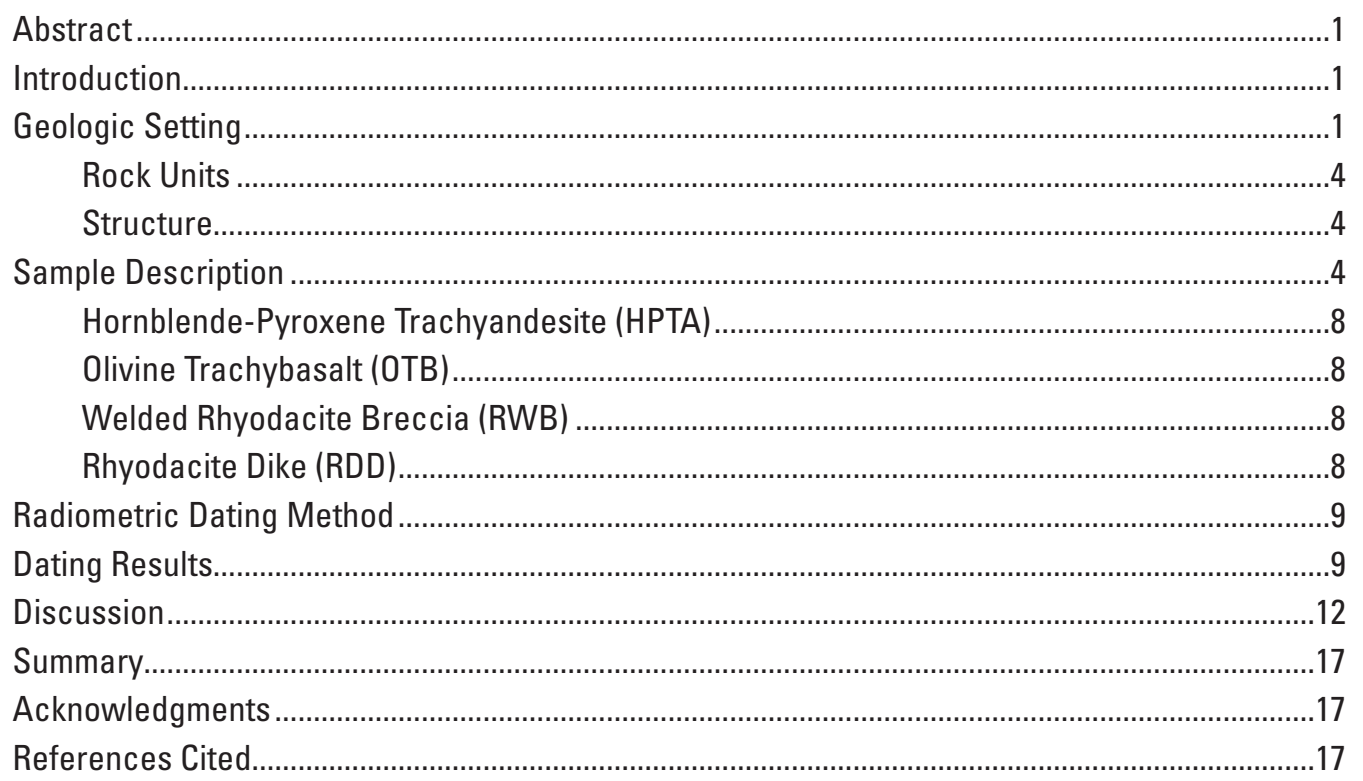

\section{Figures}

1. Map showing location of Fort Rock dome and Aquarius Mountains eruptive center......2

2. The Reconnaissance Geologic Map of Fuis (1996; his fig. 3) ............................................

3. Graphs showing incremental heating results for sample HPTA ......................................13

4. Graphs showing incremental heating results for sample OTB ....................................14

5. Graphs showing incremental heating results for sample RWB ...................................15

6. Graphs showing incremental heating results for sample RDD ......................................16

\section{Tables}

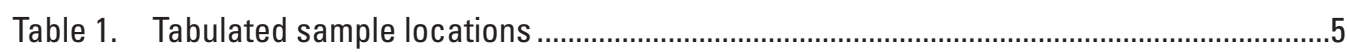

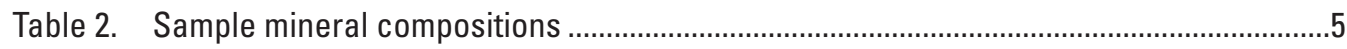

Table 3. Chemical and normative compositions .........................................................................

Table 4. $\quad{ }^{40} \mathrm{Ar} /{ }^{39} \mathrm{Ar}$ ages from the Fort Rock dome and the Aquarius Mountains .............................

Table 5. Tabulated radiometric data of HPTA groundmass .......................................................10

Table 6. Tabulated radiometric data of OTB groundmass .........................................................

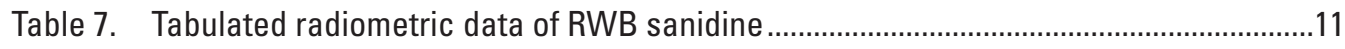

Table 8. Tabulated radiometric data of RDD plagioclase ............................................................... 


\title{
Conversion Factors
}

International System of Units to U.S. customary units

\begin{tabular}{|c|c|c|}
\hline Multiply & By & To obtain \\
\hline \multicolumn{3}{|c|}{ Length } \\
\hline meter $(\mathrm{m})$ & 3.281 & foot $(\mathrm{ft})$ \\
\hline kilometer $(\mathrm{km})$ & 0.6214 & mile (mi) \\
\hline \multicolumn{3}{|c|}{ Area } \\
\hline square kilometer $\left(\mathrm{km}^{2}\right)$ & 247.1 & acre \\
\hline square kilometer $\left(\mathrm{km}^{2}\right)$ & 0.3861 & square mile $\left(\mathrm{mi}^{2}\right)$ \\
\hline \multicolumn{3}{|c|}{ Mass } \\
\hline $\operatorname{gram}(\mathrm{g})$ & 0.03527 & ounce, avoirdupois (oz) \\
\hline
\end{tabular}

Temperature in degrees Celsius $\left({ }^{\circ} \mathrm{C}\right)$ may be converted to degrees Fahrenheit $\left({ }^{\circ} \mathrm{F}\right)$ as

$$
{ }^{\circ} \mathrm{F}=\left(1.8 \times{ }^{\circ} \mathrm{C}\right)+32 .
$$

Temperature in degrees Fahrenheit $\left({ }^{\circ} \mathrm{F}\right)$ may be converted to degrees Celsius $\left({ }^{\circ} \mathrm{C}\right)$ as ${ }^{\circ} \mathrm{C}=\left({ }^{\circ} \mathrm{F}-32\right) / 1.8$.

\section{Abbreviations}

\author{
HPTA hornblende-pyroxene trachyandesite \\ $\mathrm{Ma}$ mega annum \\ m.y. duration of millions of years \\ OTB olivine trachybasalt \\ RWB welded rhyodacite breccia \\ RDD rhyodacite dike \\ TRIGA U.S. Geological Survey training, research, isotopes, and general atomics \\ USGS U.S. Geological Survey \\ XRF X-ray fluorescence
}




\title{
Radiometric Ages of Volcanic Rocks on the Fort Rock Dome and in the Aquarius Mountains, Yavapai and Mohave Counties, Arizona
}

\author{
By Gary S. Fuis, Andrew Calvert, and Katie Sullivan
}

\begin{abstract}
The Fort Rock dome, in Yavapai County, Ariz., is a roughly circular geologic structure in plan view, $2.5 \mathrm{~km}$ in diameter, that is similar in many ways to an impact crater; however, it is a structural dome caused by a potassic mafic intrusion at depth, and the craterlike depression in its center is erosional in origin. The Aquarius Mountains, west of the Fort Rock dome, in Mohave County, contain a felsic volcanic center that erupted tuffs, non-welded ash-flow tuffs, and lahars following dome emplacement.

This report discusses the radiometric ages of samples of rock units from both the Fort Rock dome and the Aquarius Mountains eruptive center. The ages for all samples span a short interval of time from 22.3 to 21.7 m.y. (earliest Miocene). The individual sample ages are consistent with the stratigraphic order of the rock units in the area, and the short age span is consistent with the absence of any significant unconformities in the section.
\end{abstract}

\section{Introduction}

The Fort Rock dome, in Yavapai County, Ariz., and the adjacent Aquarius Mountains to the west, in Mohave County, were most recently mapped in the late 1960's and early 1970's by Fuis (1973, 1996) (figs. 1, 2). The motivation for mapping the dome, which appears as a distinctive circular crater on aerial photographs, was to determine whether or not it originated as a meteorite impact crater. The motivation for mapping the eruptive center west of the dome was to establish the sequence of volcanic events as they related to dome emplacement. The Aquarius Mountains eruptive center appeared to be a major center for ash-flow tuffs and other felsic volcanic units in a region extending from the dome to the west edge of the Colorado Plateau Transition Zone, approximately $16 \mathrm{~km}$ west of the dome. Other mapping in the region now includes an eastwest strip map north of Fort Rock dome extending approximately along the corridor of current Interstate 40 (Goff and others, 1983) and mapping of the Mohon Mountains and Hope Mountain volcanic fields south and southeast of the dome
(Simmons, 1990; Simmons and Ward, 1992). Ages acquired from the Fort Rock dome and Aquarius Mountains eruptive center will establish a chronology of volcanic events in these locations and will lead to their placement in the context of more recent geologic mapping in the region. Samples from the Fort Rock dome and Aquarius Mountains eruptive center are earliest Miocene (22.3 to 21.7 Ma) and samples from the Mohon Mountains and Hope Mountain volcanic fields range in age from early to late Miocene (22-5 Ma; Simmons and Ward, 1992). The Peach Spring Tuff (18.78 Ma; Ferguson and others, 2013) separates rocks of the Aquarius Mountains and Mohon Mountains volcanic fields where they overlap (Simmons and Ward, 1992).

\section{Geologic Setting}

Rocks exposed in the vicinity of the Fort Rock dome range in age from Precambrian to Quaternary. Precambrian igneous and metamorphic rocks and Tertiary volcanic rocks are the primary units that are exposed in this area (fig. 2). Volcanic rocks crop out over an area about $2,600 \mathrm{~km}^{2}$ in extent largely north, west, and south of the dome, in both Yavapai and Mohave counties, Ariz., but other volcanic fields are present eastward to the San Francisco peaks, near Flagstaff, Ariz. (Goff and others, 1983). Numerous volcanic centers are scattered throughout the vicinity of the Fort Rock dome, which is one relatively small center. The slightly younger Aquarius Mountains rhyodacite eruptive center, located $8 \mathrm{~km}$ southwest of the dome's center, is larger, with dimensions from rim to rim ranging from 3-5 km (Fuis, 1996) (figs. 1, 2). The chief structure in the vicinity of the dome is an east-west-striking fault that curves southeastward near the dome's SW flank (Fuis, 1996) (fig. 2). This fault postdates rocks of the Aquarius Mountains eruptive center. Faults of other orientations are present, including northerly striking basin-and-range faults near the Cottonwood Cliffs, west of Fort Rock dome (Goff and others, 1983) (figs. 1, 2). Most Phanerozoic rocks are relatively flat lying. The Fort Rock dome is an anomalous area where Tertiary rocks are folded and faulted (Fuis, 1996). 

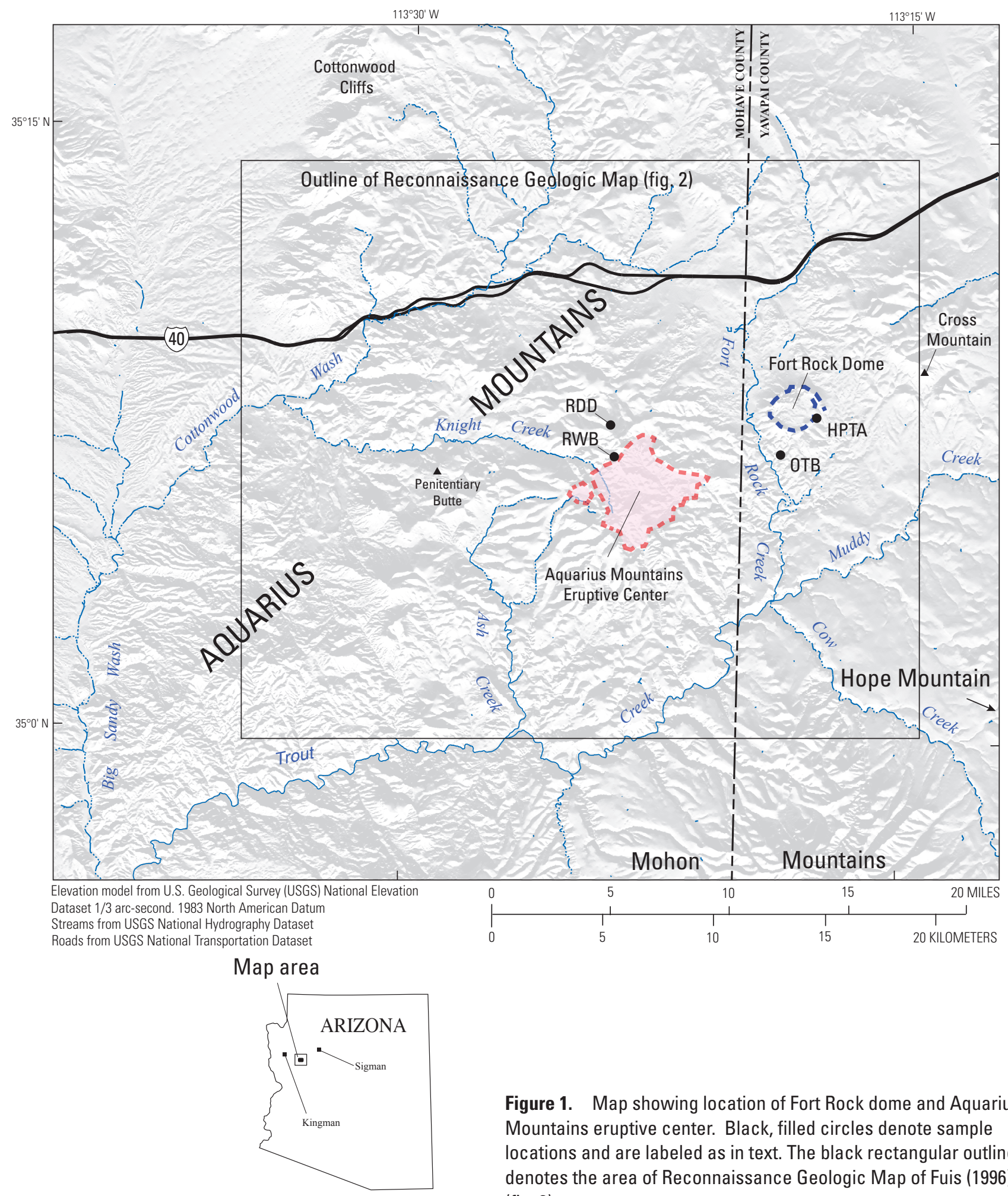

Figure 1. Map showing location of Fort Rock dome and Aquarius Mountains eruptive center. Black, filled circles denote sample locations and are labeled as in text. The black rectangular outline denotes the area of Reconnaissance Geologic Map of Fuis (1996) (fig. 2). 


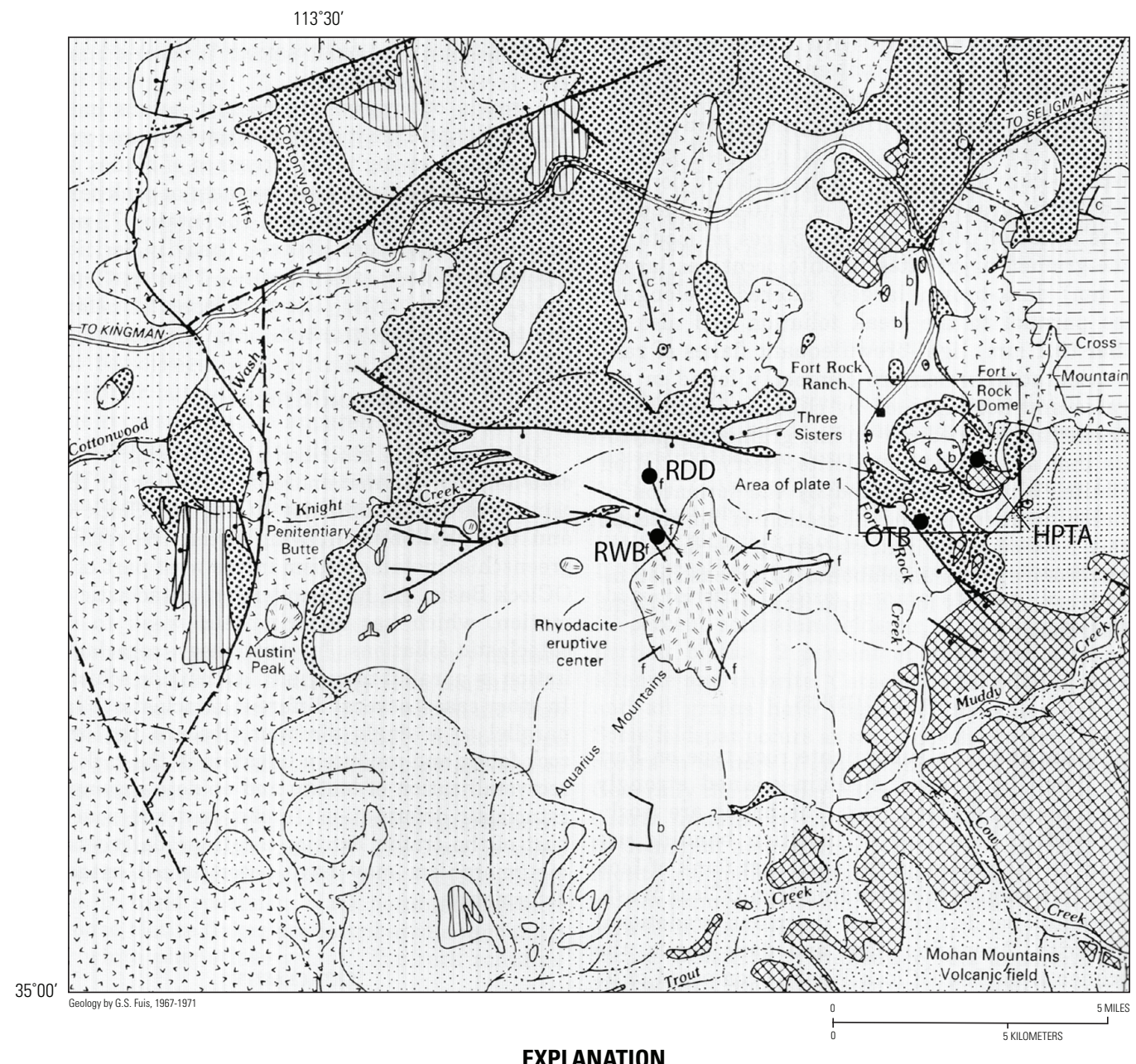

Quaternary

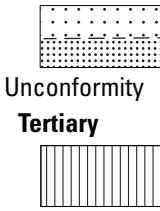

Surficial deposits-Wide-spaced dots indicate alluvium; close-spaced dots, terrace deposits

Peach Springs Tuff of Young (1966)

Uncomformity (?)

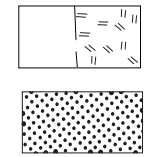

Fort Rock Creek Rhyodacite-Pattern indicates intrusive rock

Crater Pasture Formation

Unconformity

Paleozoic

-_-_-_ Redwall Limestone, unnamed Devonian carbonate rock,

Muav Limestone, Bright Angel Shale, and Tapeats Sandstone

Unconformity

Precambrian

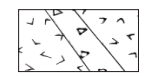

Layered metamorphic rocks, cataclasites, granite, and pegmatite-Triangles indicate Precambrian shear zone

Contact-Queried where uncertain

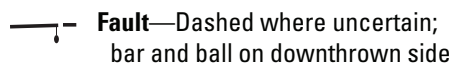

c Dike-b, basalt or andesite
f, Fort Rock Creek Rhyodacite
c, Crater Pasture Formation

Rhyodacite and dacite

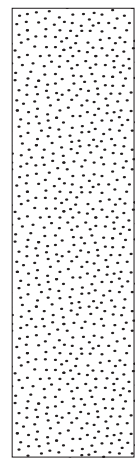

Undivided volcanic and sedimentary rocks

Figure 2. The reconnaissance geologic map of Fuis (1996; his fig. 3). Sample locations (from our fig. 1) are plotted on this map. The rectangle labeled "Area of Plate 1" is the area of the detailed geologic map in Fuis (1996). 
Radiometric Ages of Volcanic Rocks on the Fort Rock Dome and in the Aquarius Mountains, Arizona

\section{Rock Units}

Precambrian rocks on or near Fort Rock dome include layered metamorphic rocks of epidote-amphibolite facies that are intruded (or apparently intruded) by two separate groups of granitic rocks; one group crushed and foliated along with the host rocks and the other group crushed but not foliated. The entire assemblage resembles older Precambrian rocks in the Grand Canyon. On the dome, the Precambrian rocks are fractured and veined in an east-west-trending shear zone that crosses the south half of the dome. Most fracturing and veining in this zone is Precambrian in age (Fuis, 1996).

Tertiary volcanic rocks overlie a lower to middle Tertiary erosion surface that covered most of northwest Arizona (Young and McKee, 1978). In the vicinity of the Fort Rock dome, these rocks comprise two formations, the Crater Pasture Formation and Fort Rock Creek Rhyodacite; the Crater Pasture Formation is ultramafic to intermediate in composition and older, and the Fort Rock Creek Rhyodacite is felsic and younger (Fuis, 1996). Volcanic rocks in the region younger than these two formations include the Peach Spring Tuff, of middle Miocene age (Young and Brennan, 1974; Ferguson and others, 2013), which overlies the Fort Rock Creek Rhyodacite $16 \mathrm{~km}$ west of the dome, and the Mohon Mountains volcanic field, south of Trout Creek, which overlies the Peach Spring Tuff (Simmons, 1990; Simmons and Ward, 1992).

The Crater Pasture Formation includes ultramafic to intermediate lava flows, agglomerates, tuffs, and associated intrusive and sedimentary rocks on the Fort Rock dome in an area of about $300 \mathrm{~km}^{2}$ largely west, north, and south of the dome. Eleven subunits are recognized in the vicinity of the dome. Most of the rocks in these subunits originated from vents on or near the periphery of the Fort Rock dome and are traceable for distances of $2 \mathrm{~km}$ or less. The youngest unit in the formation is an olivinesanidine-trachybasalt flow, referred to as the "flow of Fault Canyon" (Fuis, 1996). This flow was erupted from a vent on the southwest flank of the dome and is interpreted to have come from a magma body beneath the dome that caused the doming.

The Fort Rock Creek Rhyodacite includes ash-flow and other massive tuffs, volcanic breccias, lava flows, and associated intrusive and sedimentary rocks in the Aquarius Mountains and vicinity. Four subunits are recognized; two are major rock units in the area and are designated members. The older member is the Old Stage Road Member, a unit consisting chiefly of non-welded ash-flow tuff. The younger member is the Three Sisters Butte Member, a unit of interbedded volcanic breccia and massive tuff. Most of the Fort Rock Creek Rhyodacite was erupted from the large center in the Aquarius Mountains, the center of which is located approximately $8 \mathrm{~km}$ southwest of the Fort Rock dome's center.

\section{Structure}

Precambrian structures on the dome include folds of different amplitudes in the layered metamorphic rocks and an east-west trending shear zone in the south half of the dome that brings together different rock assemblages and rocks of slightly different metamorphic grade. This shear zone appears to be associated with a major aeromagnetic discontinuity in Precambrian rocks in northwest Arizona (Sauck and Sumner, 1971), and we infer it to be a zone of weakness along which the body of magma was intruded that ultimately created the Fort Rock dome.

Tertiary structures on the dome include relatively minor faults that predate the uplift of the dome and the dome itself, with its associated folds and faults. The dome is a structural dome with its central part now deeply eroded (Fuis, 1996). Its edge is, in most places, a sharp circular monocline, approximately $2.5 \mathrm{~km}$ in diameter. Structural relief on the dome is $400 \mathrm{~m}$. Dips on the steeply dipping limb of the monocline, where dips can be measured accurately, range from about $40^{\circ}$ to nearly vertical and average about $66^{\circ}$. Units of the Crater Pasture Formation older than the Fault Canyon flow reflect these strong dips, whereas the Fault Canyon flow and units of the Fort Rock Creek Rhyodacite dip much more gently on the circular monocline. Most observable faults on the dome are confined to the vicinity of the monocline, perhaps partly as a result of poor exposure and lack of structural control in the deeply eroded central part of the dome. These faults have chiefly radial and tangential strikes and steep dips, where attitudes can be determined. Normal dip-slip movement appears to have been dominant, although radial faults may have had a strike-slip component of movement. Block rotations are observed along relatively long faults. Ages of faults, where they can be determined, range from the beginning of uplift, which was signaled by deposition of a sedimentary breccia on the flanks of the dome ("sedimentary breccia of One O'Clock Wash" and "sedimentary breccia of Noon Gorge" of Fuis, 1996), to after the emplacement of the ash-flow tuff (Old Stage Road Member) of the Fort Rock Creek Rhyodacite. The major offsets, however, appear to have occurred during the deposition of sedimentary breccia. In addition to mapped faults on the rim of the crater, abundant small faults with displacements of centimeters to several meters and lenses of largely unmineralized breccia were formed during doming. These are best seen in the Precambrian rocks within the crater.

The history of doming at the Fort Rock dome includes an initial stage of accelerating uplift followed by slower uplift or collapse upon formation of a vent for the magma. Domal uplift ceased upon crystallization of the magma (Fuis, 1996).

\section{Sample Description}

Two samples from the Crater Pasture Formation and two samples of the overlying Fort Rock Creek Rhyodacite have been radiometrically dated (table 1; figs. 1,2). The two samples from the Crater Pasture Formation include a stratigraphically lower hornblende-pyroxene trachyandesite ("flow of Lion Ridge"; Fuis, 1996), that was deformed on the dome, and the olivine-sanidine trachybasalt ("flow of Fault Canyon"; Fuis, 1996) that is interpreted to have been erupted on the southwest flank of the dome from the magma body that caused the doming (Fuis, 1996). The two samples from the Fort Rock 
Creek Rhyodacite are a welded rhyodacite breccia that appears to be laterally equivalent to the ash-flow tuff of the Old State Road Member and a rhyodacite dike that intrudes both members of the Fort Rock Creek Rhyodacite.

Modal and chemical/normative compositions of the two samples of the Crater Pasture Formation are given in Fuis (1996; his tables 2 and 3, respectively). The hornblende-pyroxene trachyandesite is similar to sample $154 \mathrm{f}$ in both of those tables; the olivine-sanidine trachybasalt is similar to samples $406 \mathrm{a}$ and $406 \mathrm{~b}$ in those tables. All four of the samples that were radiometrically dated in this report were examined in thin section, new modal estimates were performed, and X-ray fluorescence (XRF) chemical analyses were obtained (tables 2 and 3).

Table 1. Tabulated sample locations

[Elevation of each sample is given in both feet ( $\mathrm{ft}$ ) and meters (m)]

\begin{tabular}{lllll}
\hline Sample & Latitude $\mathbf{N}$. & Longitude $\mathbf{W}$ & Elevation (ft) & Elevation (m) \\
\hline HPTA & $35^{\circ} 08^{\prime} 00.8^{\prime \prime}$ & $113^{\circ} 17^{\prime} 52.0^{\prime \prime}$ & 5,114 & 1,559 \\
OTB & $35^{\circ} 07^{\prime} 10.7^{\prime \prime}$ & $113^{\circ} 18^{\prime} 48.1^{\prime \prime}$ & 4,942 & 1,506 \\
RWB & $35^{\circ} 07^{\prime} 03.5^{\prime \prime}$ & $113^{\circ} 23^{\prime} 31.3^{\prime \prime}$ & 5,759 & 1,755 \\
RDD & $35^{\circ} 06^{\prime} 50.2^{\prime \prime}$ & $113^{\circ} 23^{\prime} 38.82^{\prime \prime}$ & 5,784 & 1,763 \\
'F78-85 $^{\text {IF }}$ & $35^{\circ} 12^{\prime}$ & $113^{\circ} 25^{\prime}$ & & \\
${ }^{\prime} \mathrm{F} 78-73$ & $35^{\circ} 14^{\prime}$ & $113^{\circ} 20^{\prime}$ & & \\
\hline
\end{tabular}

${ }^{1}$ Prior radiometrically dated samples in region of the Fort Rock dome and Aquarius Mountains, as discussed in the text

Table 2. Sample mineral compositions in weight percent

\begin{tabular}{|c|c|c|}
\hline Sample & $\begin{array}{l}\text { Hornblende-pyroxene } \\
\text { trachyandesite (HPTA) from } \\
\text { east side of Fort Rock dome }\end{array}$ & \\
\hline Mineral & $\%$ & Description \\
\hline plagiocase & 50.3 & laths in groundmass \\
\hline k-spar & 20 & macro-phenocrysts with irregular outlines \\
\hline quartz & 0 & \\
\hline augite & 10.9 & $\begin{array}{l}1.8 \% \text { grains in cores of pseudomorphs after } \\
\text { hornblende macro-phenocrysts; } 9.1 \% \text { micro- } \\
\text { phenocrysts and groundmass grains }\end{array}$ \\
\hline pigeonite & 0 & \\
\hline hornblende* & 12.2 & *pseudomorphs after macro-phenocrysts \\
\hline biotite & 0 & \\
\hline olivine & 0 & \\
\hline alteration products & & (12.2\%—-see pseudomorphs above) \\
\hline opaque minerals & 5.5 & equant granules \\
\hline apatite & 1.4 & \\
\hline calcite & 0.5 & \\
\hline Total & 100.8 & \\
\hline
\end{tabular}


Table 2. Sample mineral compositions in weight percent-Continued

\begin{tabular}{|c|c|c|}
\hline Sample & $\begin{array}{l}\text { Olivine-sanidine trachybasalt (OTB) from SW. flank of } \\
\text { Fort Rock dome }\end{array}$ & \\
\hline Mineral & $\%$ & Description \\
\hline plagiocase & 0 & \\
\hline k-spar & 75 & subhedral laths in groundmass \\
\hline quartz & 0 & \\
\hline augite & 11 & $7 \%$ macro-phenocrysts, $4 \%$ micro-phenocrysts \\
\hline pigeonite & 2.2 & $\begin{array}{l}\text { mostly laths in groundmass; some overgrowths } \\
\text { on augite }\end{array}$ \\
\hline hornblende & 0 & \\
\hline biotite* & 1 & *pseudomorphs after biotite micro-phenocrysts \\
\hline olivine* & 5 & $\begin{array}{l}\text { *pseudomorphs after olivine macro- and micro- } \\
\text { phenocrysts }\end{array}$ \\
\hline alteration products & & (6\%—-see pseudomorphs above) \\
\hline opaque minerals & 0 & \\
\hline $\begin{array}{l}\text { glass or aphanitic/low- } \\
\text { birefringent material }\end{array}$ & 0 & \\
\hline apatite & 3.4 & micro-prisms \\
\hline calcite & 1.6 & amorphous, microcrystalline \\
\hline Total & 99.2 & \\
\hline
\end{tabular}

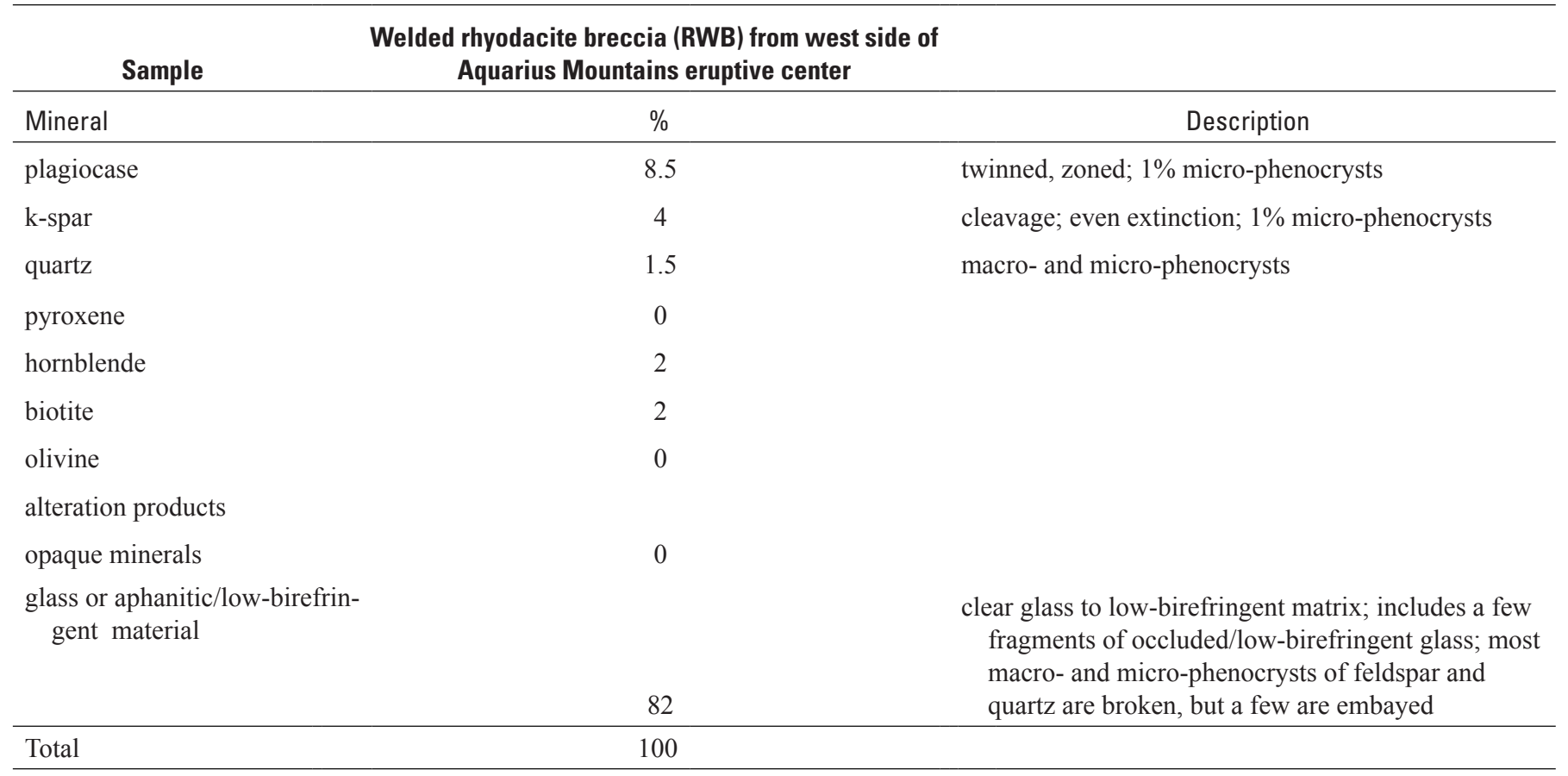


Table 2. Sample mineral compositions in weight percent-Continued

\begin{tabular}{|c|c|c|}
\hline Sample & $\begin{array}{l}\text { Rhyodacite dike (RDD) from NW. of } \\
\text { Aquarius Mountains eruptive center }\end{array}$ & \\
\hline Mineral & $\%$ & Description \\
\hline k-spar & 2.5 & $\sim 2.5 \%$ micro-phenocrysts; square outlines, zoned \\
\hline pyroxene & 0 & \\
\hline hornblende & 3 & $\begin{array}{l}\text { macro- and micro-phenocrysts; some alteration on } \\
\text { edges }\end{array}$ \\
\hline biotite & 4 & macro- and micro-phenocrysts; alteration on edges \\
\hline opaque minerals & 3 & \\
\hline $\begin{array}{l}\text { glass or aphanitic/low-birefrin- } \\
\text { gent material }\end{array}$ & 80 & low-birefringent matrix \\
\hline Total & 100 & \\
\hline
\end{tabular}

Table 3. Chemical and normative compositions in weight percent (wt \%)

\begin{tabular}{lrrrrrrrr}
\multicolumn{1}{c}{ 0xide } & HPTA & \multicolumn{1}{c}{ 154f } & \multicolumn{1}{c}{ Diff } & OTB & 406a & \multicolumn{1}{c}{ Diff } & RWB & RDD \\
\hline $\mathrm{SiO}_{2}$ & 54.17 & 54.80 & -0.63 & 53.15 & 54.10 & -0.95 & 66.77 & 64.32 \\
$\mathrm{TiO}_{2}$ & 1.15 & 1.11 & 0.04 & 0.95 & 0.95 & 0.00 & 0.41 & 0.68 \\
$\mathrm{Al}_{2} \mathrm{O}_{3}$ & 15.80 & 16.00 & -0.20 & 12.76 & 13.30 & -0.54 & 15.38 & 15.84 \\
$\mathrm{Fe}_{2} \mathrm{O}_{3}$ & & & 0.00 & & & 0.00 & & \\
$\mathrm{FeO}$ & 7.40 & 8.01 & -0.61 & 5.61 & 7.00 & -1.39 & 2.54 & 4.00 \\
$\mathrm{MnO}$ & 0.13 & 0.13 & 0.00 & 0.07 & 0.03 & 0.04 & 0.05 & 0.05 \\
$\mathrm{MgO}$ & 4.66 & 3.70 & 0.96 & 5.63 & 6.20 & -0.57 & 1.10 & 1.61 \\
$\mathrm{CaO}$ & 7.52 & 7.10 & 0.42 & 8.76 & 6.50 & 2.26 & 2.55 & 3.20 \\
$\mathrm{Na}_{2} \mathrm{O}$ & 3.83 & 3.80 & 0.03 & 2.13 & 2.10 & 0.03 & 3.92 & 4.32 \\
$\mathrm{~K}_{2} \mathrm{O}$ & 2.58 & 2.90 & -0.32 & 5.65 & 5.50 & 0.15 & 4.05 & 3.95 \\
$\mathrm{P}_{2} \mathrm{O}_{5}$ & 0.72 & 0.59 & 0.13 & 0.69 & 0.74 & -0.05 & 0.17 & 0.42 \\
$\mathrm{CO}_{2}$ & 0.00 & 0.05 & -0.05 & & 0.05 & -0.05 & -1.06 & 96.93
\end{tabular}


Table 3. Chemical and normative compositions in weight percent (wt \%) —Continued

\begin{tabular}{|c|c|c|c|c|}
\hline \multicolumn{5}{|c|}{ Normative } \\
\hline Minerals & $\begin{array}{c}\text { HPTA } \\
\text { (wt \%) }\end{array}$ & $\begin{array}{c}\text { OTB } \\
\text { (wt \%) }\end{array}$ & $\begin{array}{c}\text { RWB } \\
\text { (wt \%) }\end{array}$ & $\begin{array}{c}\text { RDD } \\
\text { (wt \%) }\end{array}$ \\
\hline Quartz & 0.00 & 0.00 & 20.65 & 13.56 \\
\hline Plagioclase & 51.75 & 26.45 & 46.06 & 49.53 \\
\hline Orthoclase & 15.60 & 34.98 & 24.70 & 23.70 \\
\hline Nepheline & 0.00 & 0.78 & 0.00 & 0.00 \\
\hline Leucite & 0.00 & 0.00 & 0.00 & 0.00 \\
\hline Kalsilite & 0.00 & 0.00 & 0.00 & 0.00 \\
\hline Corundum & 0.00 & 0.00 & 0.35 & 0.00 \\
\hline Diopside & 12.11 & 25.95 & 0.00 & 0.83 \\
\hline Hypersthene & 12.68 & 0.00 & 7.03 & 10.10 \\
\hline Wollastonite & 0.00 & 0.00 & 0.00 & 0.00 \\
\hline Olivine & 3.94 & 8.25 & 0.00 & 0.00 \\
\hline Larnite & 0.00 & 0.00 & 0.00 & 0.00 \\
\hline Acmite & 0.00 & 0.00 & 0.00 & 0.00 \\
\hline $\mathrm{K}_{2} \mathrm{SiO}_{3}$ & 0.00 & 0.00 & 0.00 & 0.00 \\
\hline $\mathrm{Na}_{2} \mathrm{SiO}_{3}$ & 0.00 & 0.00 & 0.00 & 0.00 \\
\hline Rutile & 0.00 & 0.00 & 0.00 & 0.00 \\
\hline Ilmenite & 2.22 & 1.88 & 0.80 & 1.31 \\
\hline Magnetite & 0.00 & 0.00 & 0.00 & 0.00 \\
\hline Hematite & 0.00 & 0.00 & 0.00 & 0.00 \\
\hline Apatite & 1.69 & 1.69 & 0.42 & 1.00 \\
\hline Zircon & 0.00 & 0.00 & 0.00 & 0.00 \\
\hline Perovskite & 0.00 & 0.00 & 0.00 & 0.00 \\
\hline Chromite & 0.00 & 0.00 & 0.00 & 0.00 \\
\hline Sphene & 0.00 & 0.00 & 0.00 & 0.00 \\
\hline Pyrite & 0.00 & 0.00 & 0.00 & 0.00 \\
\hline Halite & 0.00 & 0.00 & 0.00 & 0.00 \\
\hline Fluorite & 0.00 & 0.00 & 0.00 & 0.00 \\
\hline Anhydrite & 0.00 & 0.00 & 0.00 & 0.00 \\
\hline $\mathrm{Na}_{2} \mathrm{SO}_{4}$ & 0.00 & 0.00 & 0.00 & 0.00 \\
\hline Calcite & 0.00 & 0.00 & 0.00 & 0.00 \\
\hline $\mathrm{Na}_{2} \mathrm{CO}_{3}$ & 0.00 & 0.00 & 0.00 & 0.00 \\
\hline Total & 99.99 & 99.98 & 100.01 & 100.03 \\
\hline
\end{tabular}

\section{Hornblende-Pyroxene Trachyandesite (HPTA)}

Hornblende-pyroxene trachyandesite (HPTA; "flow of Lion Ridge"; Fuis, 1996) is the youngest of seven lava flows that are deformed in the circular monocline of the Fort Rock dome. It crops out around parts of the northeastern and eastern rims of the erosional crater on the dome. It contains as phenocrysts 12 percent pseudomorphs after hornblende and 2 percent augite (in the cores of pseudomorphs after hornblende). In the groundmass, it contains 50 percent plagioclase laths, 20 percent large poikilitic, irregular grains of K-spar, 9 percent augite, 5.5 percent opaque minerals (as equant granules), and 1.4 percent apatite (table 2). XRF chemical analysis of this sample gives 54.2 percent $\mathrm{SiO}_{2}$ and 2.6 percent $\mathrm{K}_{2} \mathrm{O}$ (table 3).

\section{Olivine Trachybasalt (OTB)}

Olivine trachybasalt (OTB; "flow of Fault Canyon;" Fuis, 1996) is the largely undeformed flow and intrusive unit that crops out along the southwestern flank of the Fort Rock dome. This unit is interpreted to have been erupted from a magma chamber beneath the dome that caused the doming. It contains as phenocrysts 7 percent augite and 5 percent olivine (or alteration products). In the groundmass, it contains 75 percent subhedral laths of K-spar, 4 percent augite, 3.4 percent apatite, 2.2 percent pigeonite (some as overgrowths on augite), 1.6 percent calcite, and 1 percent pseudomorphs after biotite and olivine (table 2). XRF chemical analysis of this sample gives 53.2 percent $\mathrm{SiO}_{2}$ and 5.6 percent $\mathrm{K}_{2} \mathrm{O}$ (table 3).

\section{Welded Rhyodacite Breccia (RWB)}

.31 Welded rhyodacite breccia (RWB) occurs along the western rim of the erosional lowland that overlies the Aquarius Mountains rhyodacite eruptive center (Fuis, 1996; fig. 2). It represents welding of agglomerate clasts stratigraphically below it by rhyodacite lava flows stratigraphically above it, and is interpreted to be, along with the agglomerate below it, the lateral equivalent of the Old Stage Road Member (nonwelded ash-flow tuff) of the Fort Rock Creek Rhyodacite. It contains as phenocrysts 8.5 percent twinned, zoned, broken and embayed plagioclase (including 1 percent microphenocrysts), 4 percent K-spar (including 1 percent microphenocrysts), 1.5 percent quartz (including both phenocrysts and microphenocrysts), 2 percent biotite, and 2 percent hornblende. In the groundmass, it contains 82 percent glass and low-birefringent material (table 2). XRF chemical analysis of this sample gives 66.8 percent $\mathrm{SiO}_{2}$ and 4.0 percent $\mathrm{K}_{2} \mathrm{O}$ (table $3)$.

\section{Rhyodacite Dike (RDD)}

The rhyodacite dike (RDD) extends northwestward from the western rim of the Aquarius Mountains rhyodacite eruptive center and intrudes units up through the exposed Three Sisters Butte Member of the Fort Rock Creek Rhyodacite (Fuis, 1996; fig. 2). Monoliths of this dike rock are seen along the top of the ridge intruded by this unit. It contains as phenocrysts 7.5 percent twinned and zoned plagioclase (including 2.5 percent 
microphenocrysts), 2.5 percent square, zoned plagioclase (chiefly as microphenocrysts), 4 percent biotite (as both phenocrysts and microphenocrysts), 3 percent hornblende (as both phenocrysts and microphenocrysts), and 3 percent opaque minerals. In the groundmass, it contains 80 percent lowbirefringent material (table 2). XRF chemical analysis of this sample gives 64.3 percent $\mathrm{SiO}_{2}$ and 4.0 percent $\mathrm{K}_{2} \mathrm{O}$ (table 3).

\section{Radiometric Dating Method}

${ }^{40} \mathrm{Ar} /{ }^{39} \mathrm{Ar}$ geochronology was performed on single crystals of sanidine and plagioclase and on volcanic groundmass concentrates. Minerals and groundmass separates were segregated from bulk sample by crushing, sieving, heavy liquid, and magnetic techniques. Minerals were picked under a binocular microscope. For irradiation, 16-34 milligram (mg) separates were packaged in aluminum foil and placed in a cylindrical quartz vial together with fluence monitors of known age (Taylor Creek sanidine) and K-glass and fluorite to measure interfering isotopes from $\mathrm{K}$ and $\mathrm{Ca}$. Samples and monitor materials were irradiated for ten hours in the central thimble of the U.S. Geological Survey training, research, isotopes, and general atomics (TRIGA) reactor in Denver, Colorado (Dalrymple and others, 1981). The reactor vessel was rotated continuously during irradiation to avoid lateral neutron flux gradients. Reactor constants determined for these irradiations were indistinguishable from recent irradiations, and a weighted mean of constants obtained over the past five years yields ${ }^{40} \mathrm{Ar}^{39} \mathrm{Ar}_{\mathrm{K}}$ $=0.0098 \pm 0.0002,{ }^{39} \mathrm{Ar}{ }^{37} \mathrm{Ar}_{\mathrm{Ca}}=0.000662 \pm 0.00001$, and ${ }^{36} \mathrm{Ar}^{37} \mathrm{Ar}_{\mathrm{Ca}}=0.000275 \pm 0.000003$. Sanidine from the Taylor Creek Rhyolite (TCR-2; Dalrymple and Duffield, 1988) was used as a fluence monitor with an age of $28.345 \pm 0.012$ m.y.
(Fleck and Calvert, 2016). TCR-2 is a secondary standard calibrated against the primary intralaboratory standard, GA1550 biotite, that has an age of $98.79 \pm 0.54$ m.y. (Renne and others, 1998). Fluence monitors and unknowns were analyzed using a continuous $\mathrm{CO}_{2}$ laser system and mass spectrometer described by Dalrymple (1989). Unknowns were heated in a resistance furnace with temperatures monitored by an infrared pyrometer. Gas was purified continuously during extraction using two SAES ST-175 getters, one operated hot (4 amps) and the other at room temperature.

Mass spectrometer discrimination is monitored by analyzing splits of atmospheric Ar from a reservoir attached to the extraction line, and for these samples $\mathrm{D}_{\text {lamu }}=1.010651 \pm$ 0.000161 . Typical system blanks including mass spectrometer backgrounds were $1.5 \times 10^{-18} \mathrm{~mol}$ of mass $/$ charge number $(\mathrm{m} / \mathrm{z})$ $36,9 \times 10^{-17} \mathrm{~mol}$ of $\mathrm{m} / \mathrm{z} 37,3 \times 10^{-18} \mathrm{~mol}$ of $\mathrm{m} / \mathrm{z} 39$, and $1.5 \times 10^{-}$ ${ }^{16} \mathrm{~mol}$ of $\mathrm{m} / \mathrm{z} 40$, where $\mathrm{m} / \mathrm{z}$ is mass/charge ratio. Error bars reported below are $1 \sigma$.

\section{Dating Results}

A groundmass concentrate from sample HPTA yielded a plateau age of $22.3 \pm 0.03$ m.y. using 59 percent of the ${ }^{39} \mathrm{Ar}$ released. Rejected steps suggest minor ${ }^{39} \mathrm{Ar}$ recoil. The isochron age is concordant at $22.4 \pm 0.08$ m.y. (tables 4,5 ; fig. 3). We prefer the plateau date of $22.3 \pm 0.03 \mathrm{~m} . \mathrm{y}$. as the eruption age of the HPTA flow.

Groundmass from sample OTB yielded a serially decreasing age spectrum with ages ranging from 23 to 21.3 Ma. We interpret the discordance to be due to ${ }^{39} \mathrm{Ar}$ recoil and calculate a recoil model age (Fleck and others, 2014) of 22.1 \pm 0.2 m.y. using 100 percent of the ${ }^{39} \mathrm{Ar}$ released (tables 4, 5;

Table 4. ${ }^{40} \mathrm{Ar} /{ }^{39} \mathrm{Ar}$ ages from the Fort Rock dome and the Aquarius Mountains.

[Preferred ages are listed in bold; MSWD, Mean sum weighted deviates; Ma, mega-annum; ${ }^{40} \mathrm{Ar}{ }^{36} \mathrm{Ar}_{\mathrm{i}}$, ratio at intercept]

\begin{tabular}{|c|c|c|c|c|c|c|c|c|c|c|}
\hline Sample & Material & Age (Ma) & $\begin{array}{c}{ }^{40} \mathrm{Ar} /{ }^{39} \mathrm{Ar} \\
\text { Weighted } \\
\text { mean } \\
\text { plateau age } \\
\%^{39} \mathrm{Ar} \\
{\left[\text { steps, }{ }^{\circ} \mathrm{C}\right]}\end{array}$ & MSWD & Age (Ma) & $\begin{array}{c}{ }^{40} \mathrm{Ar} /{ }^{39} \mathrm{Ar} \\
\text { isotope } \\
\text { correlation } \\
\text { (isochron) } \\
\text { age } \\
{ }^{39} \mathrm{Ar} \\
{\left[\text { steps, }{ }^{\circ} \mathrm{C}\right]}\end{array}$ & MSWD & ${ }^{40} \mathrm{Ar} /{ }^{36} \mathbf{A r}{ }_{i}$ & $\begin{array}{c}{ }^{40} \mathrm{Ar} /{ }^{39} \mathrm{Ar} \text { total } \\
\text { gas } \\
\text { Age (Ma) }\end{array}$ & Comments \\
\hline RDD & Plagioclase & $21.7 \pm 0.03$ & $\begin{array}{c}50 \\
{[1,050-1,200]}\end{array}$ & 0.53 & $21.7 \pm 0.1$ & $\begin{array}{c}50 \\
{[1,050-1,200]}\end{array}$ & 0.73 & $\begin{array}{l}309.7 \pm \\
202.1\end{array}$ & $21.7 \pm 0.03$ & Plateau Age \\
\hline RWB & Sanidine & $21.7 \pm 0.03$ & $\begin{array}{c}57 \\
{[800-1,100]}\end{array}$ & 3.00 & $21.7 \pm 0.03$ & $\begin{array}{c}57 \\
{[800-1,100]}\end{array}$ & 2.85 & $\begin{array}{l}280.7 \pm \\
110.5\end{array}$ & $21.8 \pm 0.02$ & Plateau Age \\
\hline OTB & $\begin{array}{c}\text { Ground- } \\
\text { mass }\end{array}$ & $22.1 \pm$ & $\begin{array}{c}100 \\
{[550-1,250]}\end{array}$ & 114.33 & $22.2 \pm 0.09$ & $\begin{array}{c}100 \\
{[550-1,250]}\end{array}$ & 158.37 & $\begin{array}{l}143.4 \pm \\
141.2\end{array}$ & $22.1 \pm 0.02$ & Recoil Age \\
\hline HPTA & $\begin{array}{c}\text { Ground- } \\
\text { mass }\end{array}$ & $22.3 \pm 0.03$ & $\begin{array}{c}59 \\
{[750-1,050]}\end{array}$ & 0.92 & $22.4 \pm 0.08$ & $\begin{array}{c}59 \\
{[750-1,050]}\end{array}$ & 0.79 & $\begin{array}{l}278.6 \pm \\
32.8\end{array}$ & $22.3 \pm 0.02$ & Plateau Age \\
\hline
\end{tabular}

Samples irradiated at USGS TRIGA reactor using 9.797 Ma Bodie Hills sanidine as a neutron flux monitor; R, recoil model age. 
Table 5. Tabulated radiometric data of HPTA groundmass

[Reduced with Taylor Creek Sanidine at $28.345 \pm 0.012 \mathrm{Ma}$; Ma, mega-annum; ${ }^{40} \mathrm{Ar} *$, radiogenic $\operatorname{argon} ;{ }^{40} \mathrm{Ar}-{ }^{36} \mathrm{Ar}$, measured isotopes in volts $(1.48 \mathrm{E}-13 \mathrm{moles} / \mathrm{volt})$, corrected for blank, background, discrimination, and decay; temperature is in degrees Celsius]

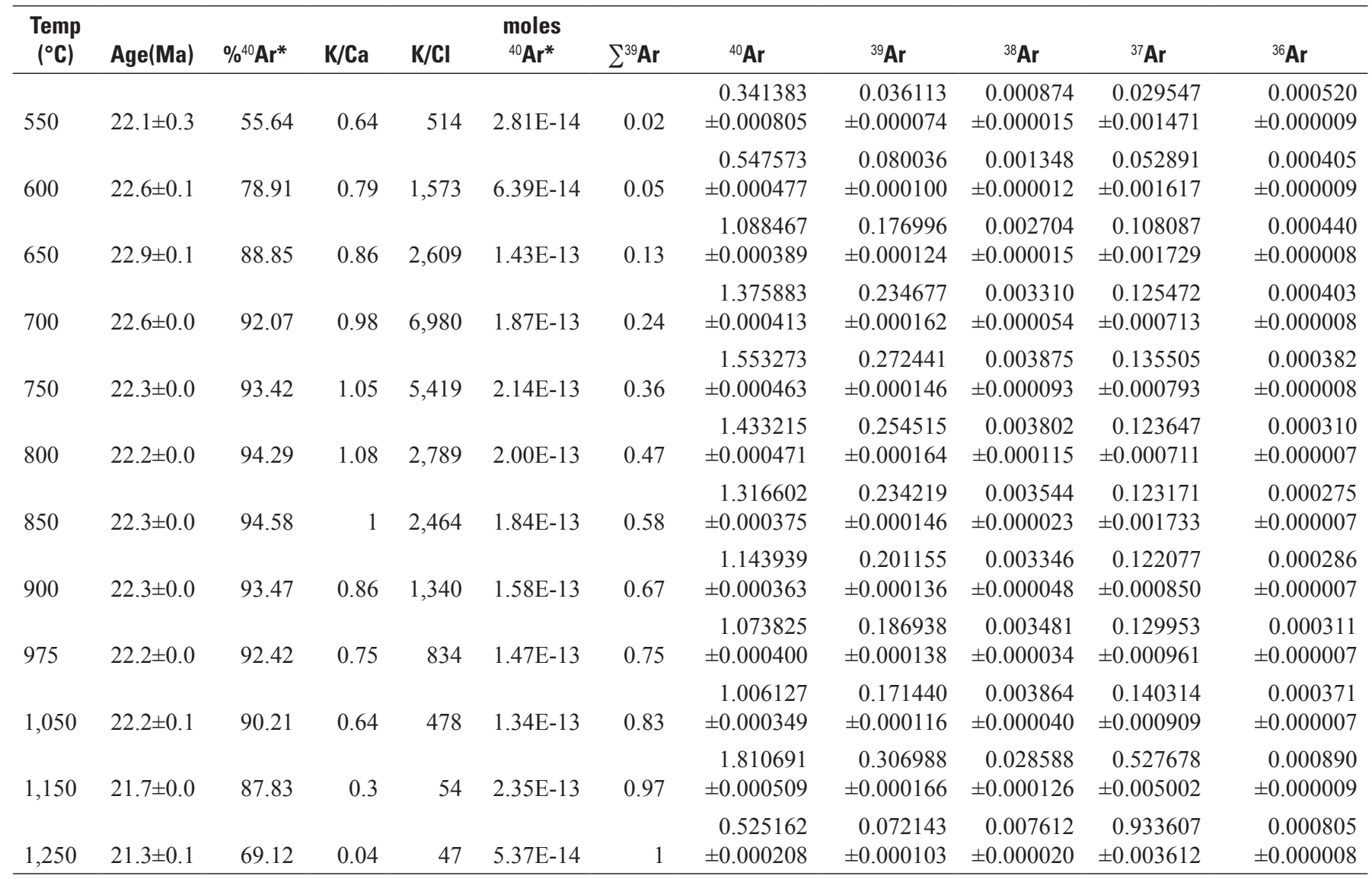

Table 6. Tabulated radiometric data of OTB groundmass

[Reduced with Taylor Creek Sanidine at $28.345 \pm 0.012 \mathrm{Ma}$; Ma, mega-annum; ${ }^{40} \mathrm{Ar} *$, radiogenic $\operatorname{argon} ;{ }^{40} \mathrm{Ar}-{ }^{36} \mathrm{Ar}$, measured isotopes in volts $(1.48 \mathrm{E}-13 \mathrm{moles} / \mathrm{volt})$, corrected for blank, background, discrimination, and decay; temperature is in degrees Celsius]

\begin{tabular}{|c|c|c|c|c|c|c|c|c|c|c|c|}
\hline $\begin{array}{c}\text { Temp } \\
\left({ }^{\circ} \mathrm{C}\right)\end{array}$ & Age(Ma) & $\%^{40} \mathbf{A r}^{*}$ & $\mathrm{~K} / \mathrm{Ca}$ & $\mathrm{K} / \mathrm{CI}$ & $\begin{array}{l}\text { moles } \\
{ }^{40} \mathrm{Ar}^{*}\end{array}$ & $\sum^{39} \mathbf{A r}$ & ${ }^{40} \mathbf{A r}$ & ${ }^{39} \mathrm{Ar}$ & ${ }^{38} \mathbf{A r}$ & ${ }^{37} \mathbf{A r}$ & ${ }^{36} \mathrm{Ar}$ \\
\hline 550 & $23.3 \pm 0.2$ & 88.43 & 0.86 & 679 & $3.73 \mathrm{E}-14$ & 0.01 & $\begin{array}{r}0.285628 \\
\pm 0.000308\end{array}$ & $\begin{array}{r}0.045315 \\
\pm 0.000067\end{array}$ & $\begin{array}{r}0.000905 \\
\pm 0.000027\end{array}$ & $\begin{array}{r}0.027774 \\
\pm 0.000358\end{array}$ & $\begin{array}{r}0.000119 \\
\pm 0.000007\end{array}$ \\
\hline 600 & $23.1 \pm 0.1$ & 92.79 & 0.75 & 905 & $1.17 \mathrm{E}-13$ & 0.03 & $\begin{array}{r}0.854290 \\
\pm 0.000515\end{array}$ & $\begin{array}{r}0.143515 \\
\pm 0.000159\end{array}$ & $\begin{array}{r}0.002614 \\
\pm 0.000120\end{array}$ & $\begin{array}{r}0.100910 \\
\pm 0.001114\end{array}$ & $\begin{array}{r}0.000236 \\
\pm 0.000008\end{array}$ \\
\hline 650 & $22.9 \pm 0.0$ & 95.12 & 1.04 & 2,172 & $2.65 \mathrm{E}-13$ & 0.08 & $\begin{array}{r}1.886327 \\
\pm 0.000486\end{array}$ & $\begin{array}{r}0.327842 \\
\pm 0.000284\end{array}$ & $\begin{array}{r}0.005032 \\
\pm 0.000171\end{array}$ & $\begin{array}{r}0.165417 \\
\pm 0.002173\end{array}$ & $\begin{array}{r}0.000357 \\
\pm 0.000009\end{array}$ \\
\hline 700 & $22.5 \pm 0.0$ & 97.54 & 2.3 & 3,169 & $3.54 \mathrm{E}-13$ & 0.15 & $\begin{array}{r}2.457457 \\
\pm 0.000753\end{array}$ & $\begin{array}{r}0.445814 \\
\pm 0.000303\end{array}$ & $\begin{array}{r}0.006523 \\
\pm 0.000096\end{array}$ & $\begin{array}{r}0.101529 \\
\pm 0.001541\end{array}$ & $\begin{array}{r}0.000232 \\
\pm 0.000008\end{array}$ \\
\hline 750 & $22.3 \pm 0.0$ & 99.23 & 4.05 & 12,467 & $4.69 \mathrm{E}-13$ & 0.24 & $\begin{array}{r}3.197321 \\
\pm 0.001014\end{array}$ & $\begin{array}{r}0.594155 \\
\pm 0.000310\end{array}$ & $\begin{array}{r}0.008058 \\
\pm 0.000157\end{array}$ & $\begin{array}{r}0.076911 \\
\pm 0.001467\end{array}$ & $\begin{array}{r}0.000104 \\
\pm 0.000006\end{array}$ \\
\hline 800 & $22.1 \pm 0.0$ & 99.51 & 4.28 & 7,433 & $6.99 \mathrm{E}-13$ & 0.38 & $\begin{array}{r}4.755471 \\
\pm 0.001428\end{array}$ & $\begin{array}{r}0.892466 \\
\pm 0.000365\end{array}$ & $\begin{array}{r}0.012303 \\
\pm 0.000124\end{array}$ & $\begin{array}{r}0.109288 \\
\pm 0.002088\end{array}$ & $\begin{array}{r}0.000109 \\
\pm 0.000007\end{array}$ \\
\hline 900 & $22.0 \pm 0.0$ & 99.27 & 5.42 & 3,096 & $6.76 \mathrm{E}-13$ & 0.67 & $\begin{array}{r}4.609833 \\
\pm 0.001387\end{array}$ & $\begin{array}{r}0.868940 \\
\pm 0.000297\end{array}$ & $\begin{array}{r}0.012688 \\
\pm 0.000096\end{array}$ & $\begin{array}{r}0.084086 \\
\pm 0.000777\end{array}$ & $\begin{array}{r}0.000137 \\
\pm 0.000007\end{array}$ \\
\hline 950 & $22.0 \pm 0.0$ & 99.23 & 5.44 & 2,007 & $5.12 \mathrm{E}-13$ & 0.77 & $\begin{array}{r}3.494824 \\
\pm 0.001416\end{array}$ & $\begin{array}{r}0.658804 \\
\pm 0.000329\end{array}$ & $\begin{array}{r}0.010116 \\
\pm 0.000042\end{array}$ & $\begin{array}{r}0.063520 \\
\pm 0.000833\end{array}$ & $\begin{array}{r}0.000109 \\
\pm 0.000007\end{array}$ \\
\hline
\end{tabular}


Table 6. Tabulated radiometric data of OTB groundmass-Continued

[Reduced with Taylor Creek Sanidine at $28.345 \pm 0.012 \mathrm{Ma}$; Ma, mega-annum; ${ }^{40} \mathrm{Ar} *$, radiogenic argon; ${ }^{40} \mathrm{Ar}-{ }^{36} \mathrm{Ar}$, measured isotopes in volts $(1.48 \mathrm{E}-13 \mathrm{moles} /$ volt), corrected for blank, background, discrimination, and decay; temperature is in degrees Celsius]

\begin{tabular}{|c|c|c|c|c|c|c|c|c|c|c|c|}
\hline $\begin{array}{c}\text { Temp } \\
\left({ }^{\circ} \mathrm{C}\right)\end{array}$ & Age(Ma) & $\%{ }^{40} \mathbf{A r}^{*}$ & $\mathrm{~K} / \mathrm{Ca}$ & $\mathrm{K} / \mathrm{CI}$ & $\begin{array}{c}\text { moles } \\
{ }^{40} \mathrm{Ar}^{*}\end{array}$ & $\sum^{39} \mathbf{A r}$ & ${ }^{40} \mathrm{Ar}$ & ${ }^{39} \mathrm{Ar}$ & ${ }^{38} \mathbf{A r}$ & ${ }^{37} \mathbf{A r}$ & ${ }^{36} \mathbf{A r}$ \\
\hline 1,025 & $21.9 \pm 0.0$ & 98.78 & 4.22 & 776 & $4.46 \mathrm{E}-13$ & 0.86 & $\begin{array}{r}3.055405 \\
\pm 0.002911\end{array}$ & $\begin{array}{r}0.575268 \\
\pm 0.000417\end{array}$ & $\begin{array}{r}0.010795 \\
\pm 0.000078\end{array}$ & $\begin{array}{r}0.071474 \\
\pm 0.001249\end{array}$ & $\begin{array}{r}0.000145 \\
\pm 0.000008\end{array}$ \\
\hline 1,100 & $21.8 \pm 0.0$ & 97.76 & 2.32 & 337 & $3.72 \mathrm{E}-13$ & 0.93 & $\begin{array}{r}2.572058 \\
\pm 0.000856\end{array}$ & $\begin{array}{r}0.480867 \\
\pm 0.000234\end{array}$ & $\begin{array}{r}0.012501 \\
\pm 0.000086\end{array}$ & $\begin{array}{r}0.108555 \\
\pm 0.001079\end{array}$ & $\begin{array}{r}0.000224 \\
\pm 0.000007\end{array}$ \\
\hline 1,175 & $21.6 \pm 0.0$ & 94.9 & 0.38 & 39 & $1.96 \mathrm{E}-13$ & 0.98 & $\begin{array}{r}1.398446 \\
\pm 0.000577\end{array}$ & $\begin{array}{r}0.257323 \\
\pm 0.000135\end{array}$ & $\begin{array}{r}0.031632 \\
\pm 0.000169\end{array}$ & $\begin{array}{r}0.352398 \\
\pm 0.001911\end{array}$ & $\begin{array}{r}0.000338 \\
\pm 0.000008\end{array}$ \\
\hline 1,250 & $21.7 \pm 0.1$ & 96.1 & 0.09 & 101 & $1.22 \mathrm{E}-13$ & 1 & $\begin{array}{r}0.860127 \\
\pm 0.000285\end{array}$ & $\begin{array}{r}0.159858 \\
\pm 0.000106\end{array}$ & $\begin{array}{r}0.008885 \\
\pm 0.000051\end{array}$ & $\begin{array}{r}0.942331 \\
\pm 0.001948\end{array}$ & $\begin{array}{r}0.000372 \\
\pm 0.000008\end{array}$ \\
\hline
\end{tabular}

Table 7. Tabulated radiometric data of RWB sanidine

[Reduced with Taylor Creek Sanidine at $28.345 \pm 0.012 \mathrm{Ma}$; Ma, mega-annum; ${ }^{40} \mathrm{Ar} *$, radiogenic $\operatorname{argon} ;{ }^{40} \mathrm{Ar}-{ }^{36} \mathrm{Ar}$, measured isotopes in volts $(1.48 \mathrm{E}-13 \mathrm{moles} /$ volt), corrected for blank, background, discrimination, and decay; temperature is in degrees Celsius]

\begin{tabular}{|c|c|c|c|c|c|c|c|c|c|c|c|}
\hline $\begin{array}{l}\text { Temp } \\
\left({ }^{\circ} \mathrm{C}\right)\end{array}$ & Age (Ma) & $\%^{40} \mathbf{A r}^{*}$ & $\mathrm{~K} / \mathrm{Ca}$ & $\mathrm{K} / \mathrm{Cl}$ & $\begin{array}{c}\text { moles } \\
{ }^{40} \mathrm{Ar}^{*}\end{array}$ & $\sum^{39} \mathbf{A r}$ & ${ }^{40} \mathrm{Ar}$ & ${ }^{39} \mathrm{Ar}$ & ${ }^{38} \mathbf{A r}$ & ${ }^{37} \mathbf{A r}$ & ${ }^{36} \mathbf{A r}$ \\
\hline 600 & $20.4 \pm 0.2$ & 77.6 & 3.53 & 221 & $3.58 \mathrm{E}-14$ & 0 & $\begin{array}{r}0.312407 \\
\pm 0.000877\end{array}$ & $\begin{array}{r}0.049036 \\
\pm 0.000065\end{array}$ & $\begin{array}{r}0.001644 \\
\pm 0.000109\end{array}$ & $\begin{array}{r}0.007283 \\
\pm 0.001005\end{array}$ & $\begin{array}{r}0.000238 \\
\pm 0.000009\end{array}$ \\
\hline 700 & $21.6 \pm 0.1$ & 96.35 & 7.55 & 1649 & $1.44 \mathrm{E}-13$ & 0.02 & $\begin{array}{r}1.012749 \\
\pm 0.000384\end{array}$ & $\begin{array}{r}0.186424 \\
\pm 0.000228\end{array}$ & $\begin{array}{r}0.002968 \\
\pm 0.000130\end{array}$ & $\begin{array}{r}0.012963 \\
\pm 0.001165\end{array}$ & $\begin{array}{r}0.000128 \\
\pm 0.000007\end{array}$ \\
\hline 750 & $21.8 \pm 0.0$ & 98.59 & 12.14 & 20,735 & $1.86 \mathrm{E}-13$ & 0.04 & $\begin{array}{r}1.273364 \\
\pm 0.000435\end{array}$ & $\begin{array}{r}0.237443 \\
\pm 0.000186\end{array}$ & $\begin{array}{r}0.003193 \\
\pm 0.000018\end{array}$ & $\begin{array}{r}0.010265 \\
\pm 0.000380\end{array}$ & $\begin{array}{r}0.000064 \\
\pm 0.000007\end{array}$ \\
\hline 800 & $21.7 \pm 0.0$ & 98.8 & 20.23 & $-2,354,795$ & $3.13 \mathrm{E}$ & 0.07 & $\begin{array}{r}2.145867 \\
\pm 0.000536\end{array}$ & $\begin{array}{r}0.403755 \\
\pm 0.000222\end{array}$ & $\begin{array}{r}0.005341 \\
\pm 0.000065\end{array}$ & $\begin{array}{r}0.010473 \\
\pm 0.000516\end{array}$ & $\begin{array}{r}0.000090 \\
\pm 0.000007\end{array}$ \\
\hline 850 & $21.7 \pm 0.0$ & 99.19 & 19.67 & 37,465 & $4.64 \mathrm{E}-13$ & 0.12 & $\begin{array}{r}3.168540 \\
\pm 0.000929\end{array}$ & $\begin{array}{r}0.597659 \\
\pm 0.000221\end{array}$ & $\begin{array}{r}0.007968 \\
\pm 0.000089\end{array}$ & $\begin{array}{r}0.015943 \\
\pm 0.000506\end{array}$ & $\begin{array}{r}0.000091 \\
\pm 0.000007\end{array}$ \\
\hline 900 & $21.7 \pm 0.0$ & 99.3 & 27.44 & 64,050 & $6.60 \mathrm{E}-13$ & 0.19 & $\begin{array}{r}4.502349 \\
\pm 0.001360\end{array}$ & $\begin{array}{r}0.851067 \\
\pm 0.000358\end{array}$ & $\begin{array}{r}0.011303 \\
\pm 0.000074\end{array}$ & $\begin{array}{r}0.016276 \\
\pm 0.000443\end{array}$ & $\begin{array}{r}0.000111 \\
\pm 0.000007\end{array}$ \\
\hline 1,050 & $21.7 \pm 0.0$ & 99.64 & 30.44 & 10,569 & $1.12 \mathrm{E}-12$ & 0.49 & $\begin{array}{r}7.639330 \\
\pm 0.002298\end{array}$ & $\begin{array}{r}1.446113 \\
\pm 0.000501\end{array}$ & $\begin{array}{r}0.019679 \\
\pm 0.000120\end{array}$ & $\begin{array}{r}0.024930 \\
\pm 0.000644\end{array}$ & $\begin{array}{r}0.000100 \\
\pm 0.000008\end{array}$ \\
\hline 1,100 & $21.8 \pm 0.0$ & 99.8 & 33.48 & 28,670 & $1.14 \mathrm{E}-12$ & 0.61 & $\begin{array}{r}7.706124 \\
\pm 0.002573\end{array}$ & $\begin{array}{r}1.459663 \\
\pm 0.000547\end{array}$ & $\begin{array}{r}0.019481 \\
\pm 0.000109\end{array}$ & $\begin{array}{r}0.022879 \\
\pm 0.000502\end{array}$ & $\begin{array}{r}0.000057 \\
\pm 0.000008\end{array}$ \\
\hline 1,150 & $21.8 \pm 0.0$ & 99.52 & 40.7 & 300 & $1.09 \mathrm{E}-12$ & 0.73 & $\begin{array}{r}7.380466 \\
\pm 0.002460\end{array}$ & $\begin{array}{r}1.390698 \\
\pm 0.000448\end{array}$ & $\begin{array}{r}0.038294 \\
\pm 0.000240\end{array}$ & $\begin{array}{r}0.017928 \\
\pm 0.000417\end{array}$ & $\begin{array}{r}0.000125 \\
\pm 0.000008\end{array}$ \\
\hline 1,200 & $21.8 \pm 0.0$ & 99.6 & 39.48 & 17,626 & $1.15 \mathrm{E}-12$ & 0.85 & $\begin{array}{r}7.830880 \\
\pm 0.002016\end{array}$ & $\begin{array}{r}1.476845 \\
\pm 0.000521\end{array}$ & $\begin{array}{r}0.019859 \\
\pm 0.000072\end{array}$ & $\begin{array}{r}0.019628 \\
\pm 0.000717\end{array}$ & $\begin{array}{r}0.000111 \\
\pm 0.000008\end{array}$ \\
\hline
\end{tabular}


Table 8. Tabulated radiometric data of RDD plagioclase

[Reduced with Taylor Creek Sanidine at $28.345 \pm 0.012 \mathrm{Ma}$; Ma, mega-annum; ${ }^{40} \mathrm{Ar} *$, radiogenic $\operatorname{argon} ;{ }^{40} \mathrm{Ar}-{ }^{36} \mathrm{Ar}$, measured isotopes in volts $(1.48 \mathrm{E}-13 \mathrm{moles} /$ volt), corrected for blank, background, discrimination, and decay; temperature is in degrees Celsius]

\begin{tabular}{|c|c|c|c|c|c|c|c|c|c|c|c|}
\hline $\begin{array}{l}\text { Temp } \\
\left({ }^{\circ} \mathrm{C}\right)\end{array}$ & Age(Ma) & $\%{ }^{40} \mathbf{A r}^{*}$ & K/Ca & $\mathrm{K} / \mathrm{Cl}$ & $\begin{array}{c}\text { moles } \\
{ }^{40} \mathrm{Ar}^{*}\end{array}$ & $\sum^{39} \mathbf{A r}$ & ${ }^{40} \mathrm{Ar}$ & ${ }^{39} \mathrm{Ar}$ & ${ }^{38} \mathbf{A r}$ & ${ }^{37} \mathbf{A r}$ & ${ }^{36} \mathbf{A r}$ \\
\hline 600 & $18.2 \pm 1.1$ & 23.19 & 0.14 & 63 & $6.77 \mathrm{E}-15$ & 0.01 & $\begin{array}{r}0.197260 \\
\pm 0.000379\end{array}$ & $\begin{array}{r}0.010472 \\
\pm 0.000054\end{array}$ & $\begin{array}{r}0.000946 \\
\pm 0.000087\end{array}$ & $\begin{array}{r}0.039302 \\
\pm 0.001247\end{array}$ & $\begin{array}{r}0.000523 \\
\pm 0.000009\end{array}$ \\
\hline 700 & $21.3 \pm 0.2$ & 87.95 & 0.25 & 494 & $2.80 \mathrm{E}-14$ & 0.03 & $\begin{array}{r}0.215420 \\
\pm 0.000188\end{array}$ & $\begin{array}{r}0.036933 \\
\pm 0.000081\end{array}$ & $\begin{array}{r}0.000825 \\
\pm 0.000044\end{array}$ & $\begin{array}{r}0.076021 \\
\pm 0.001288\end{array}$ & $\begin{array}{r}0.000109 \\
\pm 0.000007\end{array}$ \\
\hline 800 & $21.3 \pm 0.1$ & 95.45 & 0.25 & 1,424 & $5.96 \mathrm{E}-14$ & 0.09 & $\begin{array}{r}0.422769 \pm \\
0.000220\end{array}$ & $\begin{array}{r}0.078867 \\
\pm 0.000091\end{array}$ & $\begin{array}{r}0.001292 \\
\pm 0.000046\end{array}$ & $\begin{array}{r}0.162391 \\
\pm 0.001055\end{array}$ & $\begin{array}{r}0.000110 \\
\pm 0.000007\end{array}$ \\
\hline 900 & $21.4 \pm 0.1$ & 96.47 & 0.28 & 1,520 & $1.08 \mathrm{E}-13$ & 0.19 & $\begin{array}{r}0.756103 \\
\pm 0.000331\end{array}$ & $\begin{array}{r}0.141596 \\
\pm 0.000135\end{array}$ & $\begin{array}{r}0.002287 \\
\pm 0.000047\end{array}$ & $\begin{array}{r}0.269735 \\
\pm 0.002369\end{array}$ & $\begin{array}{r}0.000164 \\
\pm 0.000007\end{array}$ \\
\hline 975 & $21.6 \pm 0.1$ & 95.79 & 0.28 & 975 & $1.16 \mathrm{E}-13$ & 0.29 & $\begin{array}{r}0.816187 \\
\pm 0.000343\end{array}$ & $\begin{array}{r}0.150709 \\
\pm 0.000127\end{array}$ & $\begin{array}{r}0.002676 \\
\pm 0.000058\end{array}$ & $\begin{array}{r}0.284562 \\
\pm 0.000966\end{array}$ & $\begin{array}{r}0.000194 \\
\pm 0.000007\end{array}$ \\
\hline 1,050 & $21.6 \pm 0.0$ & 98.67 & 0.29 & 975 & $1.70 \mathrm{E}-13$ & 0.45 & $\begin{array}{r}1.166163 \\
\pm 0.000449\end{array}$ & $\begin{array}{r}0.220845 \\
\pm 0.000110\end{array}$ & $\begin{array}{r}0.003898 \\
\pm 0.000018\end{array}$ & $\begin{array}{r}0.401824 \\
\pm 0.003586\end{array}$ & $\begin{array}{r}0.000163 \\
\pm 0.000006\end{array}$ \\
\hline 1,200 & $21.7 \pm 0.0$ & 97.86 & 0.3 & 147 & $1.84 \mathrm{E}-13$ & 0.8 & $\begin{array}{r}1.260850 \\
\pm 0.000465\end{array}$ & $\begin{array}{r}0.236243 \\
\pm 0.000128\end{array}$ & $\begin{array}{r}0.010032 \\
\pm 0.000051\end{array}$ & $\begin{array}{r}0.417970 \\
\pm 0.002369\end{array}$ & $\begin{array}{r}0.000206 \\
\pm 0.000006\end{array}$ \\
\hline 1,275 & $22.0 \pm 0.0$ & 97.71 & 0.32 & 1,343 & $1.43 \mathrm{E}-13$ & 0.92 & $\begin{array}{r}0.989705 \\
\pm 0.000318\end{array}$ & $\begin{array}{r}0.182693 \\
\pm 0.000134\end{array}$ & $\begin{array}{r}0.003011 \\
\pm 0.000020\end{array}$ & $\begin{array}{r}0.296545 \\
\pm 0.001579\end{array}$ & $\begin{array}{r}0.000158 \\
\pm 0.000007\end{array}$ \\
\hline 1,350 & $22.3 \pm 0.1$ & 94.59 & 0.28 & 3,305 & $8.57 \mathrm{E}-14$ & 1 & $\begin{array}{r}0.613041 \\
\pm 0.000260\end{array}$ & $\begin{array}{r}0.107991 \\
\pm 0.000083\end{array}$ & $\begin{array}{r}0.001588 \\
\pm 0.000029\end{array}$ & $\begin{array}{r}0.203359 \\
\pm 0.000447\end{array}$ & $\begin{array}{r}0.000168 \\
\pm 0.000007\end{array}$ \\
\hline
\end{tabular}

fig. 4). We prefer the recoil model age of $22.1 \pm 0.2 \mathrm{~m} . \mathrm{y}$. as the best estimate for OTB eruption timing. This flow is interpreted to have erupted at or near the end of dome emplacement.

Sanidine from sample RWB yielded a climbing spectrum with a plateau at $21.7 \pm 0.03$ m.y. using 57.4 percent of the ${ }^{39} \mathrm{Ar}$ released. The isochron for these plateau steps is concordant at $21.7 \pm 0.03$ m.y. (tables 4,5 ; fig. 5). We prefer the plateau date of $21.7 \pm 0.03 \mathrm{~m}$.y. for the eruption of this welded breccia RWB and its interpreted lateral equivalent, the ash-flow tuff of the Old State Road Member of the Fort Rock Creek Rhyodacite.

Plagioclase from sample RDD yielded a climbing age spectrum with ages ranging from 22.5 to21.3 Ma. Three concordant steps in the middle of the spectrum yield a plateau of $21.7 \pm 0.03 \mathrm{~m}$.y. using 50.1 percent of the ${ }^{39} \mathrm{Ar}$ released. The isochron for the three steps is concordant at $21.7 \pm 0.1$ m.y. (tables 4, 5; fig. 6). We prefer the plateau date of $21.7 \pm$ 0.03 m.y. for the intrusion of this late-stage dike RDD in the Aquarius Mountains eruptive center.

\section{Discussion}

Volcanic rocks from the Fort Rock dome and Aquarius Mountains eruptive center are earliest Miocene. Ages are, from oldest to youngest, HTPA 22.3 \pm 0.03 ; OTB $22.1 \pm 0.2$; RWB 21.7 \pm 0.03 ; and RDD $21.7 \pm 0.03$ m.y. (table 4; figures 3-6). Radiometric ages for the HTPA, OTB, RWB, and
RDD obey stratigraphic superposition within error, and were emplaced over a duration of $\sim 0.6$ million years. This relatively short duration is consistent with the absence of observed unconformities between HPTA and RWB, assuming that RWB is indeed the proximal equivalent of the Old Stage Member of the Fort Rock Creek Rhyodacite. Fuis (1996) documents fragments of felsic volcanic rocks within the upper part of the sedimentary breccia eroded from the uplifting Fort Rock dome ("sedimentary breccia of Noon Gorge"), suggesting that activity at the Aquarius Mountains eruptive center had begun before erosion of the dome had been completed. It is further documented that the ash-flow tuff of the Old Stage Road Member, the next major unit above the breccia shed from the dome, ponded around the Fort Rock dome at the same approximate elevation, suggesting that uplift of the dome was completed by the time of ash-flow eruption. The rhyodacite dike (RDD) represents the youngest felsic unit in and near the Aquarius Mountains eruptive center and cuts through both members of the Fort Rock Creek Rhyodacite. The similarity in age between RWB and RDD indicates that activity at the eruptive center was short-lived.

Ages from this study can be compared to other ages that have been obtained in the region of the Fort Rock dome and Aquarius Mountains. From west to east, these include the following:

1. An age of $18.78 \pm 0.02$ m.y. for the Peach Spring Tuff (Ferguson and others, 2013). Description of this unit was first published by Young and Brennan (1974), 

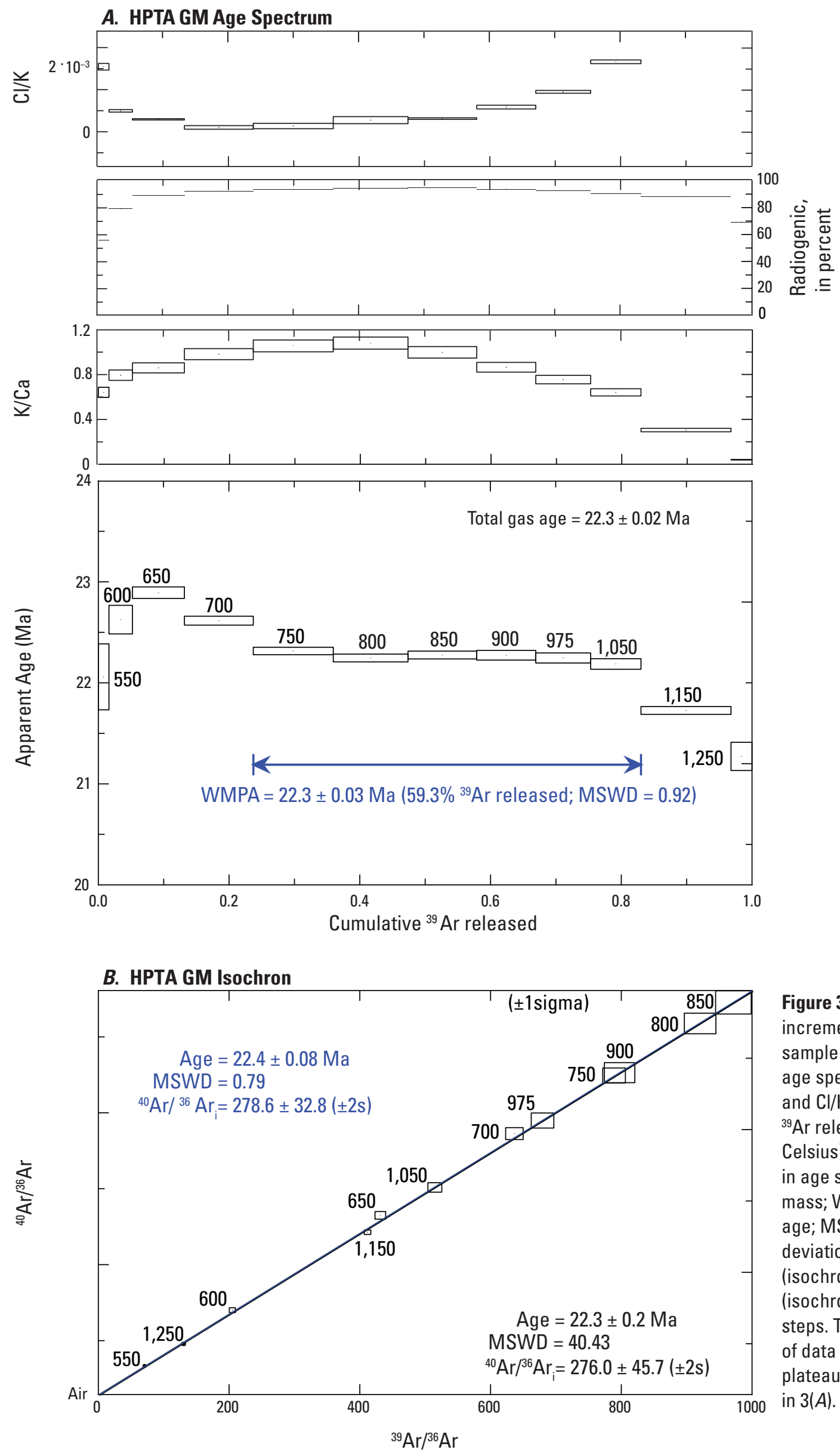

Figure 3. Graphs showing incremental heating results for sample HPTA. (A) Stacked ${ }^{40} \mathrm{Ar} /{ }^{39} \mathrm{Ar}$ age spectrum, $\mathrm{K} / \mathrm{Ca}$, radiogenic yield, and $\mathrm{Cl} / \mathrm{K}$ plotted against cumulative ${ }^{39} \mathrm{Ar}$ released. Temperatures (degrees Celsius) labeled with each increment in age spectrum diagram. GM-ground mass; WMPA--weighted mean plateau age; MSWD-mean squared weighted deviation. $(B)$ Isotope correlation (isochron) diagram. The black line (isochron) consists of data from all steps. The blue line (isochron) consists of data from only the steps on the plateau, indicated by the blue bracket in $3(A) . \mathrm{Ar}_{\mathrm{i}}$ is the $\mathrm{y}$ intercept. 


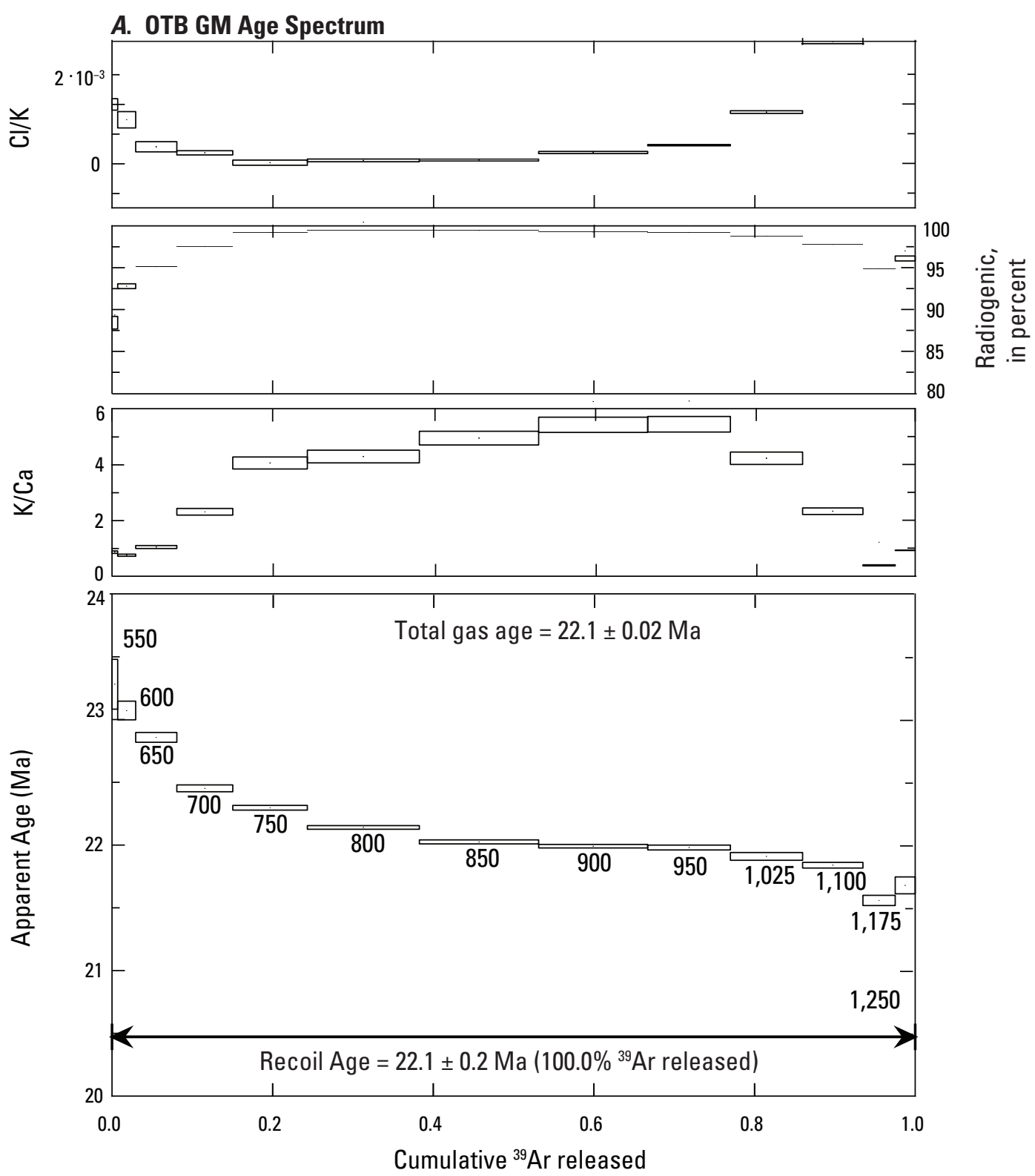

\section{B. OTB GM Isochron}

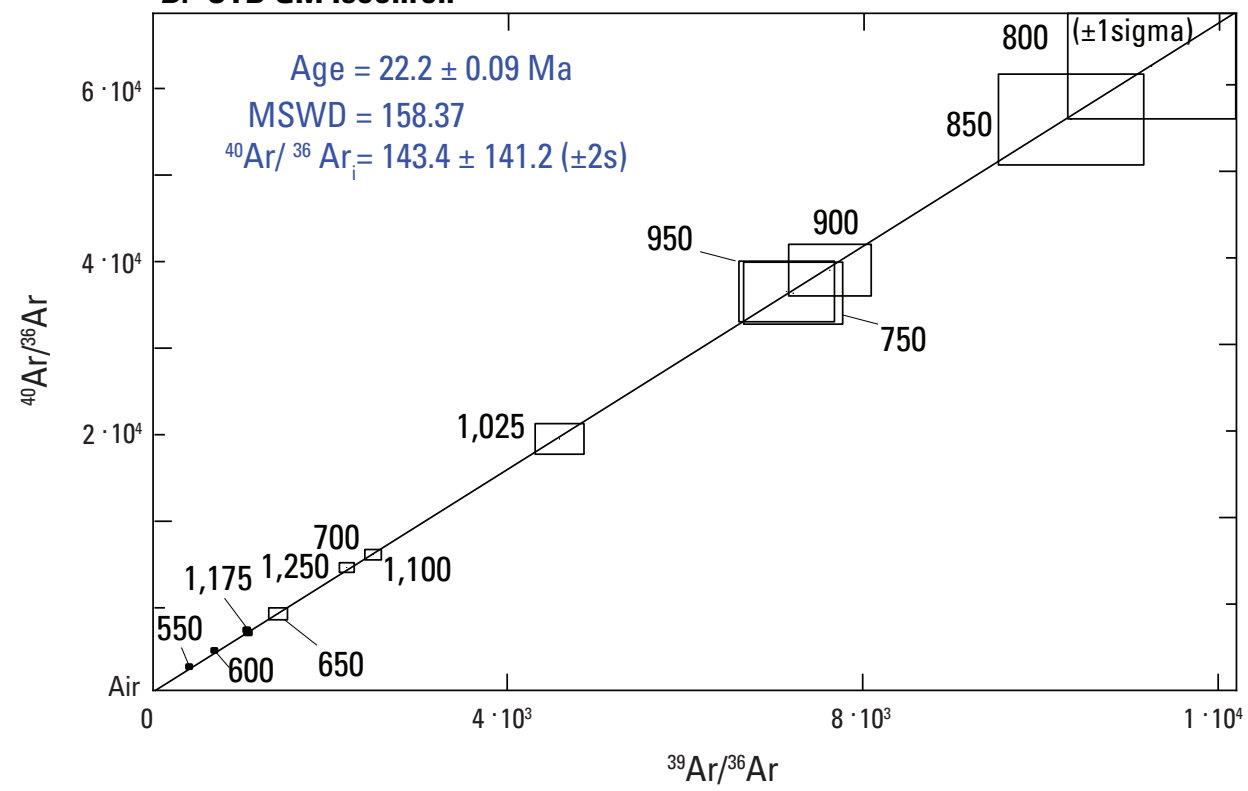

Figure 4. Graphs showing incremental heating results for sample OTB. (A) Stacked ${ }^{40} \mathrm{Ar} /{ }^{39} \mathrm{Ar}$ age spectrum, $\mathrm{K} / \mathrm{Ca}$, radiogenic yield, and $\mathrm{Cl} / \mathrm{K}$ plotted against cumulative ${ }^{39} \mathrm{Ar}$ released. Temperatures (degrees Celsius) labeled with each increment in age spectrum diagram. GM-ground mass; WMPA--weighted mean plateau age; MSWD-mean squared weighted deviation. $(B)$ Isotope correlation (isochron) diagram. $\mathrm{Ar}_{i}$ is the $\mathrm{y}$ intercept. 


\section{A. RWB Sanidine Age Spectrum}
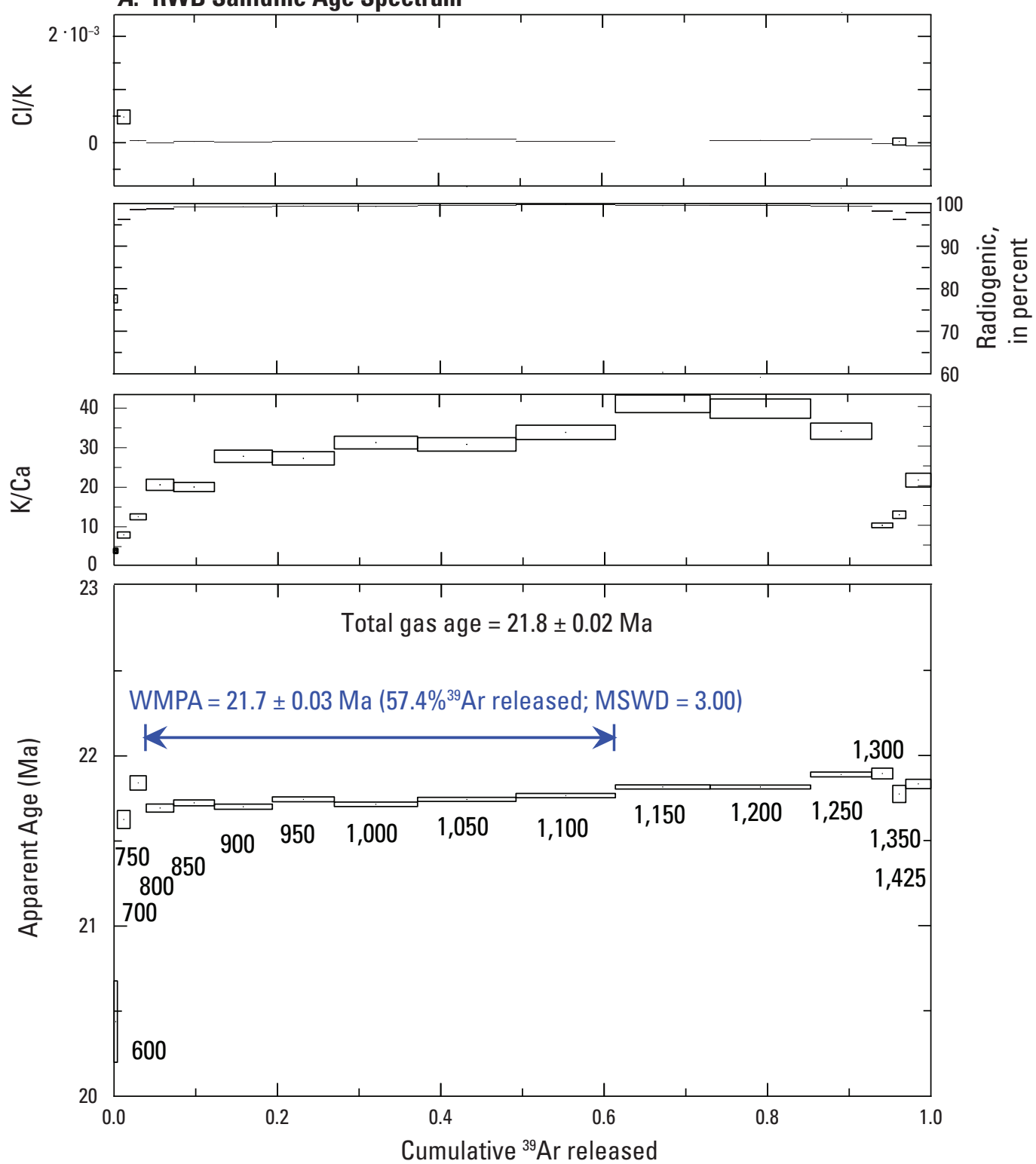

B. RWB Sanidine Isochron

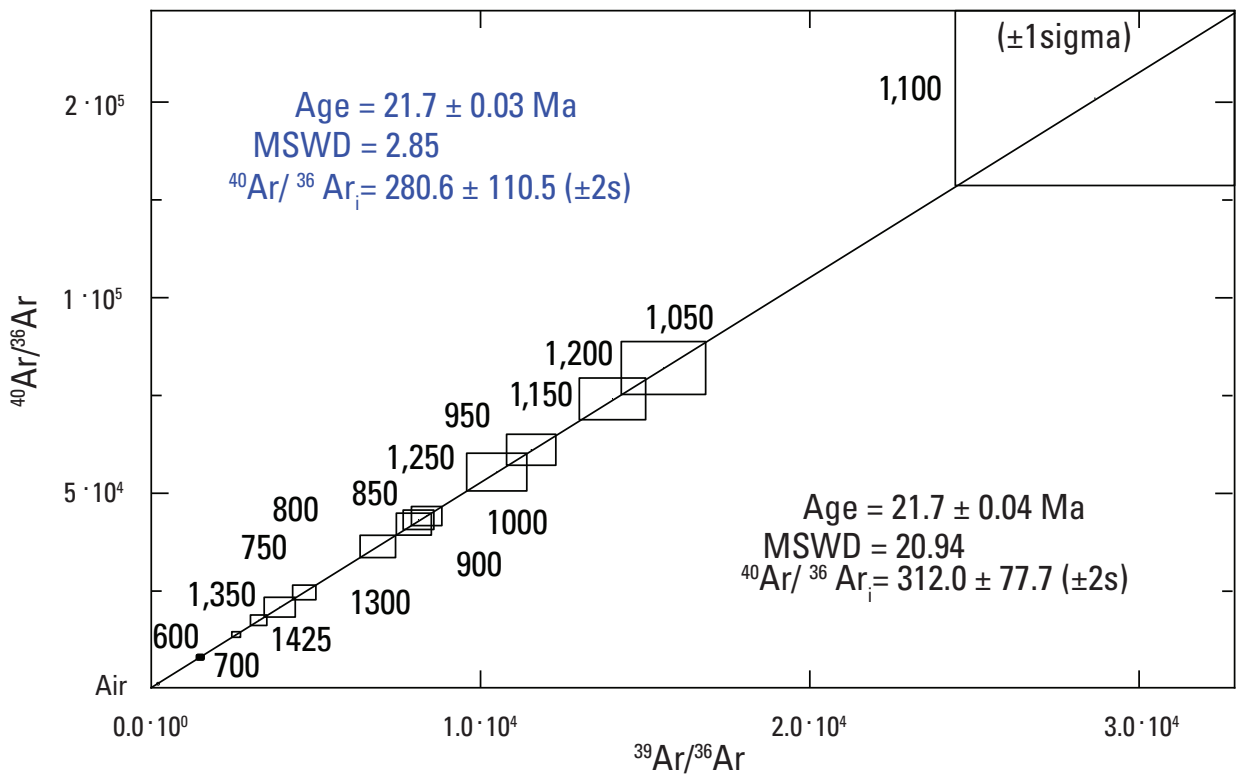

Figure 5. Graphs showing incremental heating results for sample RWB. (A) Stacked ${ }^{40} \mathrm{Ar} /{ }^{39} \mathrm{Ar}$ age spectrum, $\mathrm{K} / \mathrm{Ca}$, radiogenic yield, and $\mathrm{Cl} / \mathrm{K}$ plotted against cumulative ${ }^{39} \mathrm{Ar}$ released. Temperatures (degrees Celsius) labeled with each increment in age spectrum diagram. WMPAweighted mean plateau age; MSWDmean squared weighted deviation. $(B)$ Isotope correlation (isochron) diagram. The black line (isochron) consists of data from all steps. The blue line (isochron) consists of data from only the steps on the plateau, indicated by the blue bracket in $5(A) . A r_{i}$ is the $y$ intercept. 


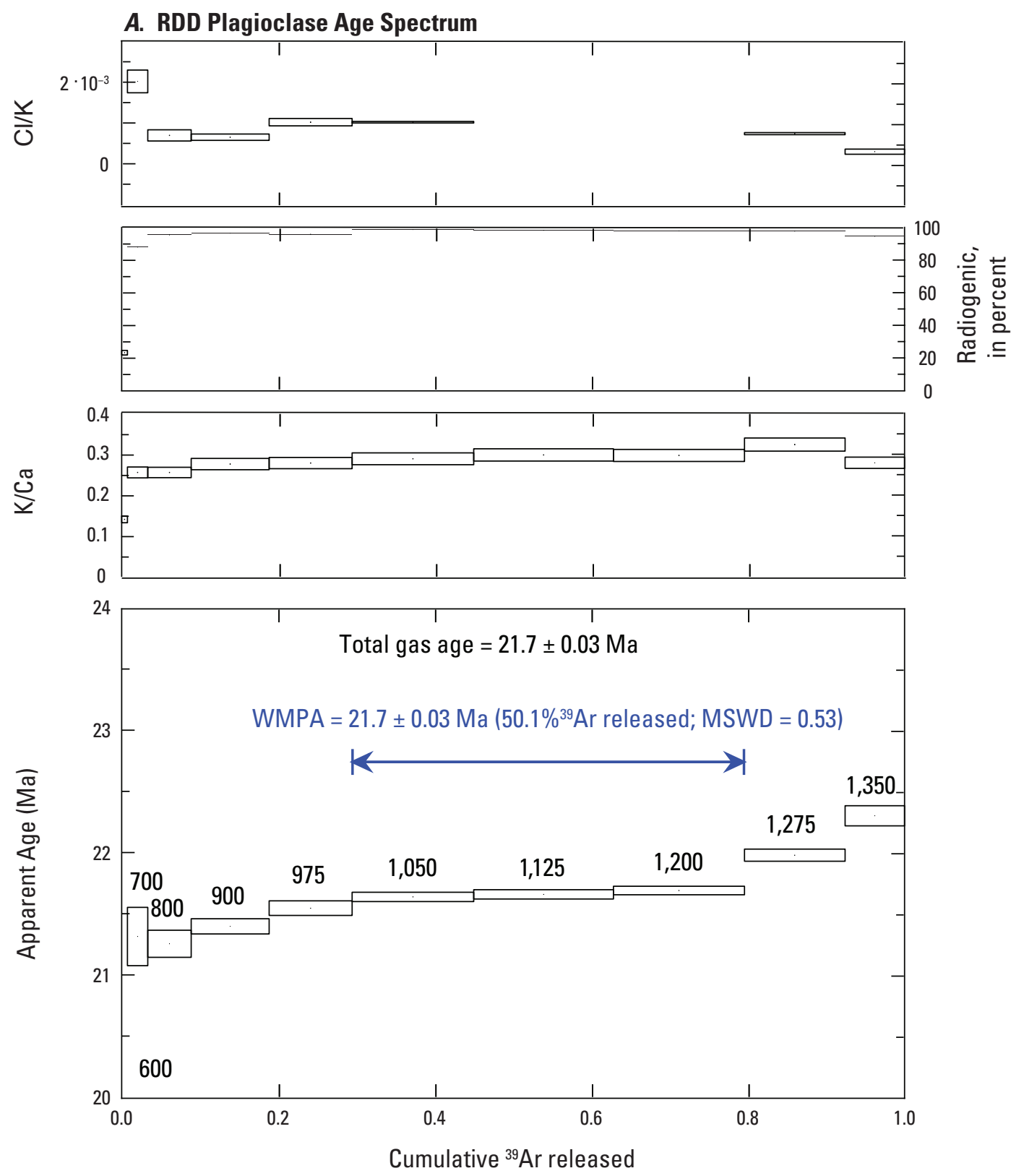

\section{B. RDD Plagioclase Isochron}

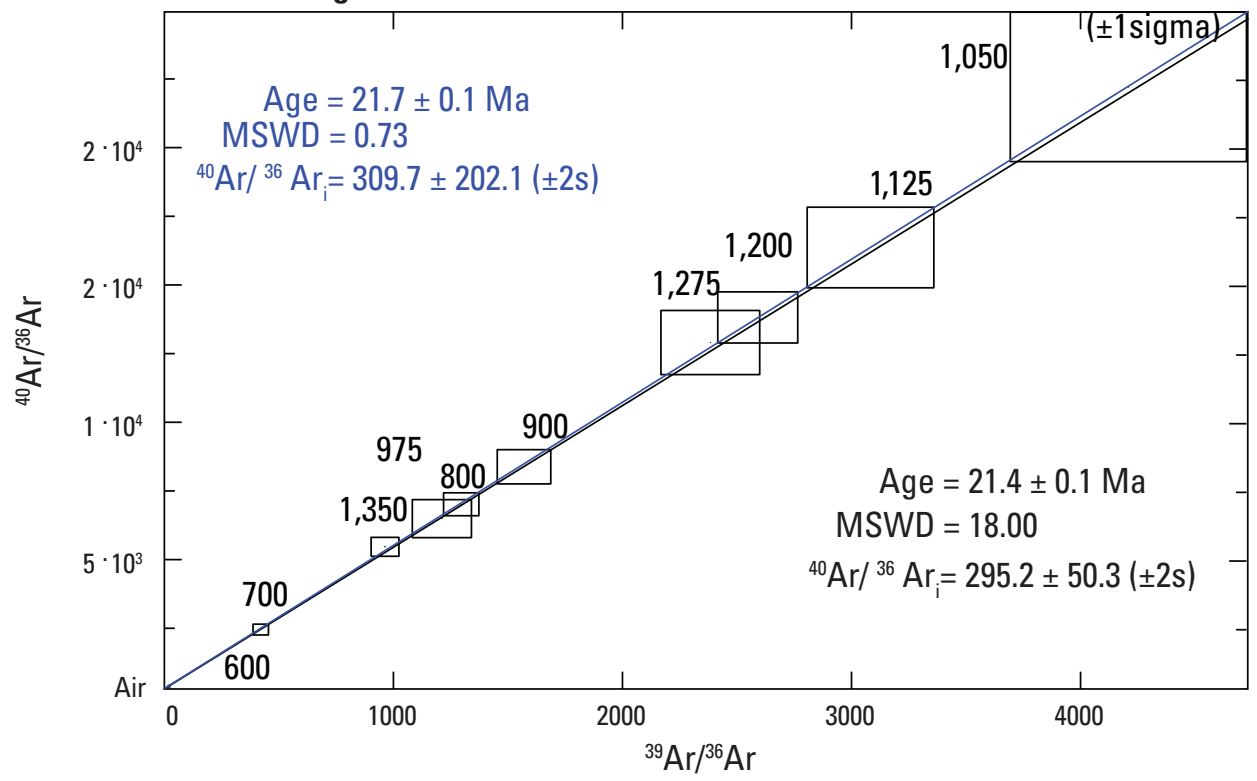

Figure 6. Graphs showing incremental heating results for sample RDD. (A) Stacked ${ }^{40} \mathrm{Ar} /{ }^{39} \mathrm{Ar}$ age spectrum, $\mathrm{K} / \mathrm{Ca}$, radiogenic yield, and $\mathrm{Cl} / \mathrm{K}$ plotted against cumulative ${ }^{39} \mathrm{Ar}$ released. Temperatures (degrees Celsius) labeled with each increment in age spectrum diagram. WMPAweighted mean plateau age; MSWDmean squared weighted deviation. $(B)$ Isotope correlation (isochron) diagram. The black line (isochron) consists of data from all steps. The blue line (isochron) consists of data from only the steps on the plateau, indicated by the blue bracket in $6(A) . \mathrm{Ar}_{i}$ is the $\mathrm{y}$ intercept. 
with a K-Ar age of 17.6 Ma. Outcrops in the Aquarius Mountains are as much as $100 \mathrm{~km}$ east of the caldera source, that is located in the Black Mountains, 40 km WSW of Kingman, Ariz. At Penitentiary Butte, located $16 \mathrm{~km}$ west of the center of the Fort Rock dome, the Peach Spring Tuff forms a cap rock. It rests above an unconformity atop the Three Sisters Butte Member of the Fort Rock Creek Rhyodacite (Fuis, 1996). This unconformity would represent approximately 2.9 Ma. Five km farther west of Penitentiary Butte, across a major north-south Basin and Range fault that extends southward from the foot of the Cottonwood Cliffs, the Peach Spring Tuff rests on both mafic igneous rocks similar to the Crater Pasture Formation and on Precambrian igneous and metamorphic rocks, at an elevation well below its outcrop on Penitentiary Butte (Fuis, 1996). It is interpreted that the block west of the Basin and Range fault first moved upward after deposition of the Fort Rock Creek Rhyodacite, allowing removal of this unit, followed by emplacement of the Peach Spring Tuff. Finally, the block west of this fault moved downward to produce the relationships seen today (Fuis, 1996).

2. An age of $22.0 \pm 0.7 \mathrm{~m}$.y. for a hornblende-olivine basalt dike that intrudes part of the Fort Rock Creek Rhyodacite $12 \mathrm{~km}$ northwest of the center of the Fort Rock dome (sample F78-85; Goff and others, 1983; our table 1). This date is consistent with the geologic relationships seen at this location, namely, the dike is younger than both the Fort Rock Rhyodacite and Crater Pasture Formation, given the error bar on its age.

3. An age of $20.7 \pm 0.6$ m.y. for a basaltic andesite flow(?) approximately $11 \mathrm{~km} \mathrm{NNW}$ of the center of the Fort Rock dome (sample BA78-73; Goff and others, 1983; our table 1). This unit is interpreted by Goff and others (1983) to be equivalent to basalts overlying (and possibly interfingering with) the Peach Spring Tuff as exposed farther north.

4. An age of $22.4 \pm 0.8$ m.y. for a biotite-pyroxene andesite intrusive (vent) rock approximately $8 \mathrm{~km}$ north of the center of the Fort Rock dome (sample F78-88; Goff and others, 1983; our table 1). This unit is overlain and surrounded by younger basalt flows. Given its age, this unit appears laterally equivalent to the Crater Pasture Formation.

The last 3 ages are potassium-argon ages obtained by Daniel Krummenacher, San Diego State University, Calif. (Goff and others, 1983).

Rocks in the Mohon Mountains and Hope Mountain volcanic fields south and southeast of Fort Rock dome (fig. 1) range in age from 22-5 m.y. (Simmons, 1990; Simmons and Ward, 1992). Rocks dated between 22 and 20 m.y. consist primarily of trachyandesite and dacite breccias and form the two large stratovolcanoes in the Mohon Mountains volcanic field. Volcanic rocks younger than 13 m.y. comprise a bimodal suite of alkalic basalt and high-silica rhyolite and form two large volcanic domes in these fields. The bulk of the volcanic rocks of these fields overlie the Peach Spring Tuff, which is exposed in the walls of Trout Creek (fig. 1).

\section{Summary}

New radiometric ages of samples taken from the Fort Rock dome and Aquarius Mountains eruptive center fall within a short time span of 0.6 m.y. in the earliest Miocene. Fort Rock dome emplacement followed eruption of seven intermediate to ultramafic lava flows by as little as 0.2 m.y. During the waning period of dome uplift and erosion, felsic eruptive activity began at the nearby Aquarius Mountains rhyodacite eruptive center. Most eruptive activity at the Aquarius Mountains eruptive center occurred in a short time interval (0.03 m.y.) around $21.7 \mathrm{Ma}$. The ages reported here all predate the Peach Spring Tuff (18.78 Ma), which overlies the Fort Rock Creek Rhyodacite in this region. The Peach Spring Tuff in turn underlies the bulk of the Mohon Mountains volcanic field south of the Fort Rock dome and Aquarius Mountains.

\section{Acknowledgments}

Reviews by Seth Burgess, John Tinsley, and Keith Knudsen improved this manuscript significantly and were much appreciated. Editing and formatting by Phil Frederick and Kimber Petersen were very helpful and got this manuscript to its final form. Luke Blair kindly drafted the index map (fig. 1).

\section{References Cited}

Dalrymple, G.B., 1989, The GLM continuous laser system for ${ }^{40} \mathrm{Ar} /{ }^{39} \mathrm{Ar}$ dating; description and performance characteristics, in Shanks, W.C., III, and Criss, R.E., eds., New frontiers in stable isotopic research; laser probes, ion probes, and small-sample analysis: U.S. Geological Survey Bulletin 1890, p. 89-96.

Dalrymple, G.B. and Duffield, W.A., 1988, High precision ${ }^{40} \mathrm{Ar} /{ }^{39} \mathrm{Ar}$ dating of Oligocene rhyolites from the MogollonDatil volcanic field using a continuous laser system: Geophysical Research Letters, v. 15, p. 463-366.

Dalrymple, G.B., Alexander E.C., Jr., Lanphere, M.A., and Kraker, G.P., 1981, Irradiation of samples for ${ }^{40} \mathrm{Ar} /{ }^{39} \mathrm{Ar}$ dating using the Geological Survey TRIGA reactor: U.S. Geological Survey, Professional Paper 1176. 55 p.

Ferguson, C.A., McIntosh, W.C., and Miller, C.F., 2013, Silver Creek caldera-The tectonically dismembered source of the Peach Spring Tuff: Geology, v. 41, p. 3-6. 
Fleck, R.J., Hagstrum, J.T., Calvert, A.T., Evarts, R.C., and Conrey, R.M., 2014, ${ }^{40} \mathrm{Ar} /{ }^{39} \mathrm{Ar}$ geochronology, paleomagnetism, and evolution of the Boring volcanic field, Oregon and Washington, USA: Geosphere, v. 10, no. 6, p. 1283-1314.

Fleck, R.J. and Calvert, A.T., 2016, Intercalibration of ${ }^{40} \mathrm{Ar} /{ }^{39} \mathrm{Ar}$ mineral standards with Bodie Hills Sanidine: Geological Society of America Abstracts with Programs. v. 48 , no. 7 , Paper no. 238-4, https://doi.org/10.1130/ abs/2016AM-286011.

Fuis, G. S., 1973, The geology and mechanics of formation of the Fort Rock dome, Yavapai County, Arizona: Pasadena, California Institute of Technology, Ph.D. dissertation, 278 p.

Fuis, G. S., 1996, The geology and mechanics of formation of the Fort Rock Dome, Yavapai County, Arizona: U.S. Geological Survey Professional Paper 1266, 95 p., 2 pl., scale 1:5000.

Goff, F.E., Eddy, A.C., and Arney, B.H., 1983, Reconnaissance geologic strip map from Kingman to south of Bill Williams Mountain, Arizona: University of California, Los Alamos National Laboratory, LA-9202-MAP, 6 sheets, scale $1: 48,000$.
Renne, P.R., Swisher, III, C.C., Deino, A.L., Karner, D.B., Owens, T., and DePaolo, D.J., 1998, Intercalibration of standards, absolute ages, and uncertainties in ${ }^{40} \mathrm{Ar} /{ }^{39} \mathrm{Ar}$ dating: Chemical Geology, v. 145, p. 117-152.

Sauck, W.A., and Sumner, J.S., 1971, Residual aeromagnetic map of Arizona: Tucson, University of Arizona, Department of Geosciences, scale 1:1,000,000.

Simmons, A.M., 1990, The Miocene Mohon Mountains volcanic field, west-central Arizona - geology, geochemistry, and petrogenesis: State University of New York at Buffalo, Ph.D. dissertation, $294 \mathrm{p}$.

Simmons, A.M., and Ward, A.W., 1992, Preliminary geologic map of the Mohon Mountains volcanic field, Mohave and Yavapai Counties, Arizona: U.S. Geological Survey OpenFile Report 92-198, 2 plates, scale 1:50,000.

Young, R.A., and Brennan, W.J., 1974, Peach Springs TuffIts bearing on structural evolution of the Colorado Plateau and development of Cenozoic drainage in Mohave County, Arizona: Geological Society of America Bulletin, v. 85, p. 83-90.

Young, R.A., and McKee, E.H., 1978, Early and middle Cenozoic drainage and erosion in west-central Arizona: Geological Society America Bulletin, v. 89, p. 1745-1750. 
Menlo Park Publishing Service Center, California

Manuscript approved for publication April 15, 2019

Edited by Phil Frederick

Layout and design by Kimber Petersen 
